KARLA YUKARI KATAYAMA

\title{
AVALIAÇÃO DO SISTEMA DE ESTABILIZAÇÃO PLASMIDIAL TOXINA-ANTITOXINA PARA A PRODUÇÃO DE PROTEÍNAS RECOMBINANTES EM ESCHERICHIA COLI
}

Dissertação apresentada ao Programa de Pós-Graduação Interunidades em Biotecnologia USP / Instituto Butantan / IPT para obtenção do Título de Mestre em Ciências.

São Paulo

2016 


\section{Karla Yukari Katayama}

Avaliação do sistema de estabilização plasmidial toxina-antitoxina para a produção de proteínas recombinantes em Escherichia coli

Dissertação apresentada ao Programa de Pós-Graduação Interunidades em Biotecnologia USP / Instituto Butantan / IPT para obtenção do Título de Mestre em Ciências.

Orientadora: Profa. Dra. Viviane Maimoni Gonçalves

Versão corrigida. A versão original eletrônica encontra-se disponível tanto na Biblioteca do ICB quanto na Biblioteca Digital de Teses e Dissertações da USP (BDTD).

São Paulo

2016 
DADOS DE CATALOGAÇÃO NA PUBLICAÇÃO (CIP)

Serviço de Biblioteca e Informação Biomédica do

Instituto de Ciências Biomédicas da Universidade de São Paulo

(c) reprodução total

Katayama, Karla Yukari.

Avaliação do sistema de estabilização plasmidial toxina-antitoxina para a produção de proteinas recombinantes em Escherichia coli I Karla Yukari Katayama. -- São Paulo, 2016.

Orientador: Profa. Dra. Viviane Maimoni Gonçalves.

Dissertação (Mestrado) - Universidade de São Paulo. Instituto de Ciências Biomédicas. Programa de Pós-Graduação Interunidades em Biotecnologia USP/IPT/Instituto Butantan. Área de concentração:

Biotecnologia. Linha de pesquisa: Desenvolvimento de bioprocessos para produção de enzimas.

Versão do título para o inglês: Evaluation of plasmidial stabilization system toxin-antitoxin for recombinant proteins production in Escherichia coli.

1. Escherichia coli 2. Proteina recombinante 3. Bioprocessos 4 . Toxina-antitoxina 5. Cultivo livre de antibióticos 6 . Estabilidade plasmidial I. Gonçalves, Profa. Dra. Viviane Maimoni II. Universidade de São Paulo. Instituto de Ciências Biomédicas. Programa de PósGraduação Interunidades em Biotecnologia USP/IPT/Instituto Butantan III. Título. 
Candidato(a):

Título da Dissertação:

Orientador(a):
Karla Yukari Katayama.

Avaliação do sistema de estabilização plasmidial toxina-antitoxina para a produção de proteínas recombinantes em Escherichia coli.

Profa. Dra. Viviane Maimoni Gonçalves.

A Comissão Julgadora dos trabalhos de Defesa da Dissertação de Mestrado, em sessão pública realizada a I. I. considerou

\section{( ) Aprovado(a)}

( ) Reprovado(a)

Examinador(a): Assinatura:

Nome:

Instituição:

Examinador(a): Assinatura:

Nome:

Instituição:

Presidente: Assinatura:

Nome:

Instituição: 
Av. Dr. Vital Brasil, 1500, CEP 05503-900, São Paulo, SP, Brasil

Telefone: (55) (011) 2627-9585 - Fax: (55) (011) 2627-9505

ceueib@butantan.gov.br

São Paulo, 20 de março de 2015

\section{CERTIFICADO}

Certificamos que o projeto "Produção de Enzimas Recombinantes em Cultivo Livre de Antibióticos", protocolo $\mathrm{n}^{\circ}$. I-1375/15, sob a responsabilidade de Viviane Maimoni Gonçalves e Karla Yukari Katayama, não envolve a criação e/ou utilização de animais pertencentes ao filo Chordata, subfilo Vertebrata, para fins de pesquisa cientifica.

This is to certify that the proposal "Production of recombinant enzymes in antibiotic-free cultivation", protocol $n^{\circ} \mathbf{I}-1375 / 15$, under the responsibility of Viviane Maimoni Gonçalves and Karla Yukari Katayama, has been reviewed by the Institute Butantan Animal Care and Use Committee, and that it does not involve breeding and/or use of animals belonging to phylum Chordata, subphylum Vertebrata, in scientific research.

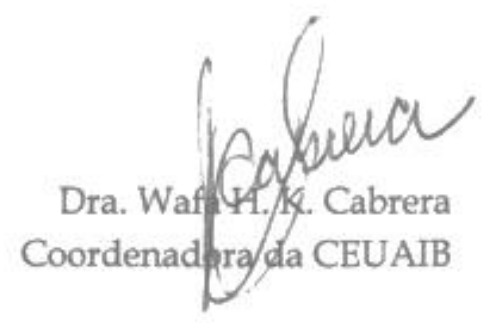




\section{AGRADECIMENTOS}

A Deus, por estar presente em todos os dias da minha vida e me dar forças para nunca desistir.

Às minhas orientadoras, Profa. Dra. Viviane Maimoni Gonçalves e Dra. Sindelia Freitas Azzoni, pelo apoio, dedicação, paciência e atenção para a concretização do projeto. Suas forças foram fundamentais para a conclusões deste trabalho.

À equipe do LBHB, principalmente Aline Tavares, Mateus Ribeiro e Marcia Luchi, que me acompanharam no dia-a-dia do laboratório pela busca deste título de mestre, pelo apoio, amizade e várias horas de companheirismo dividas na bancada.

Aos meus pais e meu irmão, que sempre me apoiaram em todas as decisões de minha vida. Grande parte desta conquista vem da força e apoio que vocês sempre me deram.

Aos amigos, antigos e novos, próximos ou distantes, pelos momentos de companheirismo divididos ao longo destes anos. 
"O sucesso nasce do querer, da determinação $e$ persistência em se chegar a um objetivo. Mesmo não atingindo o alvo, quem busca e vence obstáculos, no mínimo fará coisas admiráveis." 


\section{RESUMO}

KATAYAMA, K.Y. Avaliação do sistema de estabilização plasmidial toxinaantitoxina para a produção de proteínas recombinantes em Escherichia coli. 2016. 66 f. Dissertação (Mestrado em Biotecnologia) - Instituto de Ciências Biomédicas, Universidade de São Paulo, São Paulo, 2016.

A busca de fontes energéticas renováveis tem impulsionado a pesquisa em tecnologias mais eficientes e viáveis economicamente na produção de etanol de segunda geração. Uma abordagem promissora para a obtenção de coquetéis enzimáticos eficientes para a etapa de hidrólise é o enriquecimento de coquetéis em termos de atividades que Ihes faltam, mas podem ser obtidas através de sistemas heterólogos. Este trabalho teve como objetivo avaliar o sistema toxina-antitoxina (TA) para estabilização plasmidial em E. coli, visando reduzir os custos ao eliminar o antibiótico na produção de proteínas recombinantes. Os resultados obtidos em ensaios de cinética e expressão indicaram que o sistema de expressão na linhagem com estabilização TA é tão eficaz quanto à utilização da linhagem dependente de antibiótico para estabilização plasmidial, amplamente utilizada em escala industrial. Além de eficaz, o sistema de estabilização TA mostrou-se mais eficiente pelo fato de não permitir a sobrevivência de células sem o plasmídeo. Foi verificado que há um escape de até $10 \%$ de células sem o plasmídeo na linhagem dependente de antibiótico para manutenção do plasmídeo, mesmo na presença do antibiótico, e de até $34 \%$ sem o antibiótico durante o cultivo, o que não ocorre ao utilizar o sistema TA. Estudos indicaram a quantidade mínima de $0,05 \mathrm{mM}$ de IPTG para expressão das proteínas nesta linhagem, cerca de 20 vezes menos que a concentração usualmente aplicada, mas é importante considerar a densidade celular no momento da indução. Sendo assim, o sistema de estabilização plasmidial TA mostrou-se como uma ótima ferramenta para o desenvolvimento de uma plataforma alternativa para a produção de proteínas recombinantes.

Palavras-chave: Escherichia coli. Proteína recombinante. Bioprocessos. Toxinaantitoxina. Cultivo livre de antibióticos. Estabilidade plasmidial. 


\begin{abstract}
KATAYAMA, K.Y. Evaluation of plasmidial stabilization system toxin-antitoxin for recombinant proteins production in Escherichia coli. 2016 . 66 p. Master thesis (Biotechnology) - Instituto de Ciências Biomédicas, Universidade de São Paulo, São Paulo, 2016.

The search for renewable energy sources has driven research into more efficient and economically viable technologies for second generation ethanol production. A promising approach to obtain efficient enzyme cocktails for the hydrolysis step is the enrichment of cocktails in terms of activities that are lacking, but can be obtained by heterologous systems. The objective of this study was to evaluate the toxin-antitoxin (TA) system for plasmid stabilization in E. coli, to reduce costs by eliminating the antibiotic in the production of recombinant proteins. The results obtained in kinetic and expression assays indicated that the expression system in the strain with TA stabilization is as effective as the use of antibiotic-dependent strain for plasmid stabilization, widely used at industrial scale. Besides effective, TA stabilization system was more efficient as it does not allow the survival of cells without the plasmid. It has been found that there is a leak of up to $10 \%$ of cells without the plasmid in antibioticdependent strain for plasmid maintenance, even in the presence of the antibiotic, and up to $34 \%$ without antibiotics during cultivation, which does not occur when using the TA system. Studies have indicated the minimum amount of $0.05 \mathrm{mM}$ of IPTG for expression of proteins in this strain, about 20 times less than the concentration usually applied, but it is important to consider the cell density at time of induction. Thus, the TA plasmid stabilization system proved to be a great tool for the development of an alternative platform for producing recombinant proteins.
\end{abstract}

Keywords: Escherichia coli. Recombinant protein. Bioprocess. Toxin-antitoxin, Antibiotic-free cultivation. Plasmidial stability. 


\section{LISTA DE FIGURAS}

Figura 1 - Princípio do sistema toxina-antitoxina. Adaptado de Szpirer e Milinkovitch,

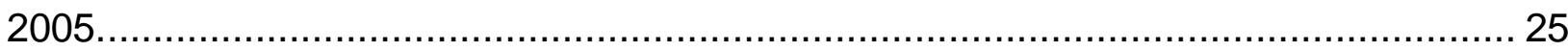

Figura 2 - Estratégia de subclonagem do cassete ccdA no plasmídeo pET28a(+) contendo os genes de $\beta$-1,3-1,4-glucanase e expansina. 30

Figura 3 - Trecho do plasmídeo pStaby, evidenciando a localização do cassete ccdA entre os sítios da enzima de restrição Sphl. 30

Figura 4 - Gel de agarose 1\% com produtos de PCR para confirmação da clonagem. 4a) Confirmação da presença do inserto de endoglucanase (1) e ccdA (2). 4b) Confirmação da presença do inserto de expansina (1) e ccdA (2). M: GeneRuler $1 \mathrm{~kb}$ Plus DNA Ladder (Thermo Scientific)

Figura 5 - Perfil cinético de crescimento a partir dos valores de absorbância nos ensaios de cultivo em frasco agitado. 5a) Cinética de crescimento das linhagens SE1 e BL21(DE3) contendo gene da endoglucanase. 5b) cinética de crescimento das linhagens SE1 e BL21(DE3) contendo o gene da expansina. 45 Figura 6 - Perfil cinético de crescimento comparando as linhagens SE1 e BL21(DE3) a partir dos valores de absorbância nos ensaios de cultivo e expressão em frasco agitado. 6a) Cinética de crescimento das linhagens SE1 e BL21(DE3) contendo gene da endoglucanase. 6b) cinética de crescimento das linhagens SE1 e BL21(DE3) contendo o gene da expansina. A linha verde vertical indica o momento da indução. . 46 Figura 7 - Gel de SDS-PAGE com amostras antes e após 3 horas de indução das proteínas endoglucanase e expansina nas linhagens SE1 e BL21. M: marcador de peso molecular (PageRuler Prestained Protein Ladder - ThermoScientific). 46 Figura 8 - Dados obtidos para curva de calibração para correlação de massa seca e absorbância. 8a) Valores de absorbância por tempo obtidos durante o cultivo. 8b) Valores de massa seca por tempo obtidos durante o cultivo. 48 Figura 9 - Curva de calibração obtida para correlação de absorbância a 600nm e biomassa seca $(\mathrm{g} / \mathrm{L})$. 
Figura 10 - Perfil cinético de crescimento em cultivo em reator de $3 \mathrm{~L}$ a partir dos valores de massa seca dos clones de expressão de endoglucanase (10a) e expansina (10b) em linhagem SE1.

Figura 11 - Perfil de consumo de substrato em cultivo em reator de $3 \mathrm{~L}$ dos clones de expressão de endoglucanase (11a) e expansina (11b) em linhagem SE1. 50 Figura 12 - Gráficos para a obtenção da velocidade específica de crescimento $\mu_{\times}$para ambos os clones em linhagem SE1. Foram plotados os valores dos logaritmos neperianos dos valores de massa seca em relação ao tempo inicial para os clones de SE1 expressando endoglucanase (12a) e expansina (12b). O valor de $\mu_{x}$ é dado pelo coeficiente angular obtido do ajuste da equação de primeira ordem aos dados da curva.

Figura 13 - Gráficos para a obtenção do fator de conversão de substrato em célula (Yx/s) para ambos os clones em linhagem SE1. Foram plotados os valores de massa seca obtidos em relação ao glicerol presente no determinado tempo para os clones expressando endoglucanase (13a) e expansina (13b). O valor de $\mathrm{Yx} / \mathrm{s}$ é dado pelo coeficiente angular obtido, expresso em gramas de células por gramas de glicerol. ... 51 Figura 14 - Número de cópias de plasmídeos por reação ao longo do cultivo. A linha verde indica o momento da indução. a) Linhagem BL21(DE3) com o plasmídeo end/pET28a. b) linhagem SE1 com o plasmídeo end_ccdA/pET28a. 53 Figura 15 - Gel de SDS-PAGE com amostras após 3 horas de indução da enzima endoglucanase na linhagem SE1 com diferentes concentrações de IPTG. M: marcador de peso molecular (Prestained Protein MW Marker - ThermoScientific). Al: amostra antes da indução. 54

Figura 16 - Comparação do perfil cinético de crescimento das linhagens SE1 e BL21(DE3) com e sem indução em ensaios em frasco agitado. 16a) Cinética de crescimento da linhagem SE1. 16b) Cinética de crescimento da linhagem BL21(DE3). 


\section{LISTA DE TABELAS}

Tabela 1 - Exemplos de biofármacos produzidos em E.coli (adaptado de BAESHEN et al., 2015)..... 19

Tabela 2 - Oligonucleotídeos utilizados na reação de PCR para confirmação da presença do gene da endoglucanase, expansina e do cassete ccdA. 34

Tabela 3 - Oligonucleotídeos utilizados na qPCR

Tabela 4 - Parâmetros obtidos ao final do cultivo nos ensaios de expressão em frasco agitado.

Tabela 5 - Parâmetros cinéticos obtidos a partir de cultivo em reator de $3 \mathrm{~L}$. 51

Tabela 6 - Estabilidade plasmidial durante a fase de indução para cultivos com e sem a presença de antibiótico, utilizando a linhagem BL21(DE3) para expressão das proteínas endoglucanase e expansina.

Tabela 7 - Estabilidade plasmidial durante a fase de indução para cultivos utilizando a linhagem SE1, sem a presença de antibiótico, para expressão das proteínas endoglucanase e expansina. 52

Tabela 8 - Dados obtidos no microensaio de determinação da concentração do indutor IPTG. 55

Tabela 9 - Dados obtidos no ensaio em reatores para determinação da concentração do indutor IPTG. 


\section{LISTA DE ABREVIATURAS E SIGLAS}

ATP - Adenosina trifosfato

bp - pares de bases

CIP - Fosfatase intestinal de bezerro

CNPEM - Centro Nacional de Pesquisas em Energia e Materiais

CTBE - Laboratório Nacional de Ciência e Tecnologia do Bioetanol

DNA - Ácido desoxirribonucleico

DNS - Ácido 3,5-dinitro-salicílico

dNTP - Desoxinucleotídeos trifosfato

DO - Densidade óptica

EDTA - ácido etilenodiamino tetra-acético

HPLC - Cromatografia líquida de alta performance

IPTG - Isopropil- $\beta$-D-tiogalactopiranosídeo

LBHB - Laboratório de Biossíntese de Hidrolases Bacterianas

mRNA - RNA mensageiro

OD - Oxigênio dissolvido

PCR - Reação da Polimerase em Cadeia

pET - plasmídeo para expressão pela polimerase T7

PMSF - Fluoreto de fenilmetilsulfonil

qPCR - real-time PCR. Reação da Polimerase em Cadeia quantitativa

RNA - Ácido ribonucleico

SDS-PAGE - Eletroforese em gel de poliacrilamida dodecil sulfato de sódio

TA - Toxina-antitoxina 
UV - Ultravioleta

VVM - Volume de ar por volume de meio por minuto 


\section{LISTA DE SÍMBOLOS}

$\mu$ - grandeza de unidade - micro $\left(10^{-6}\right)$

$\mu_{x}$ - velocidade específica de crescimento

$\mu_{\mathrm{s}}$ - velocidade específica de consumo de substrato

$P_{x}$ - Produtividade em células

So - Concentração inicial de substrato

S - Concentração de substrato

$\mathrm{t}$ - tempo de cultivo

$X_{0}$ - Concentração inicial de células

$X_{f}$ - Concentração final de células

$\mathrm{Y}_{\mathrm{x} / \mathrm{s}}$ - Fator de conversão de substrato em célula 


\section{SUMÁRIO}

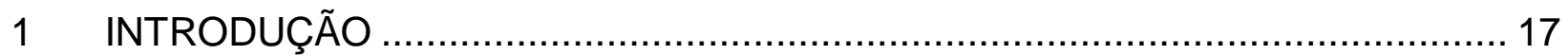

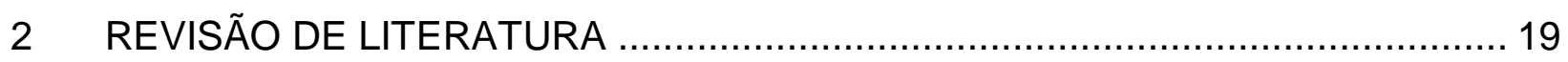

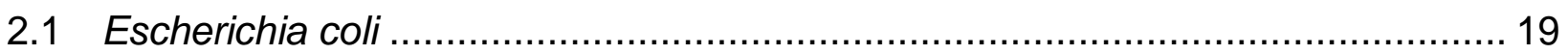

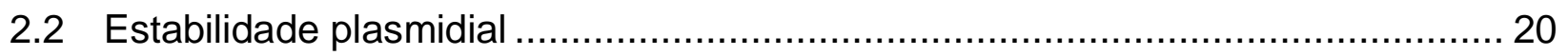

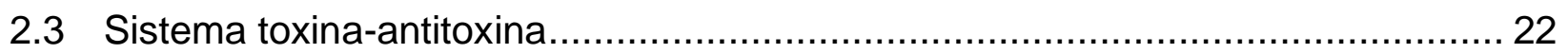

2.4 Suplementação de coquetéis enzimáticos para hidrólise de material

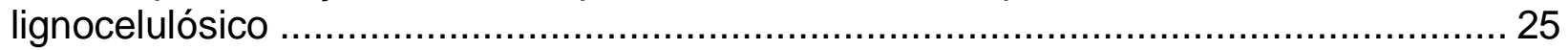

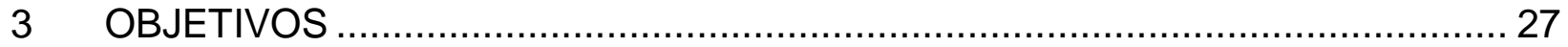

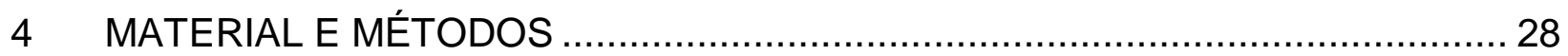

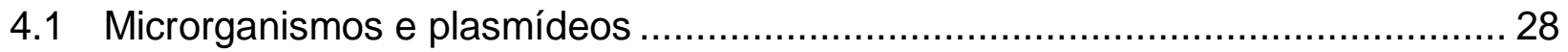

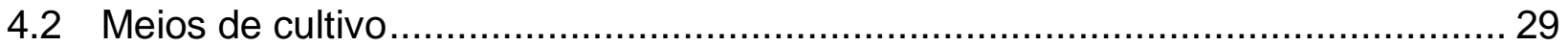

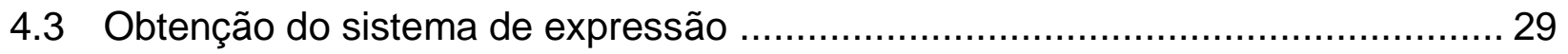

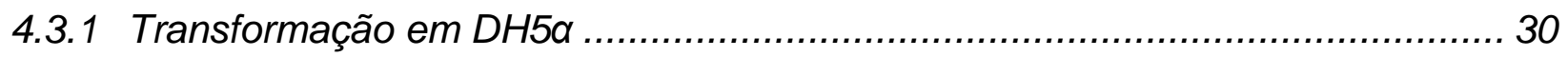

4.3.2 Extração do DNA plasmidial (miniprep) ………........................................... 31

4.3.3 Digestão dos plasmídeos com enzima de restrição ....................................... 31

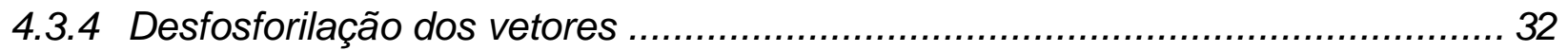

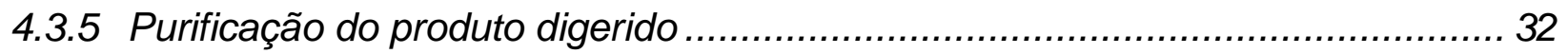

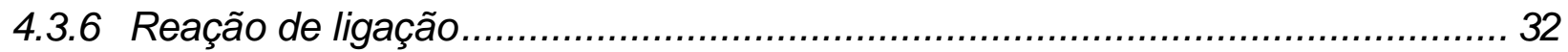

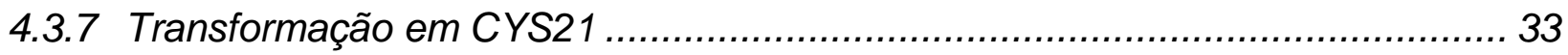

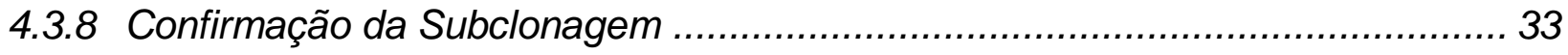

4.3.9 Transformação de células E. coli de expressão SE1 ..................................... 34

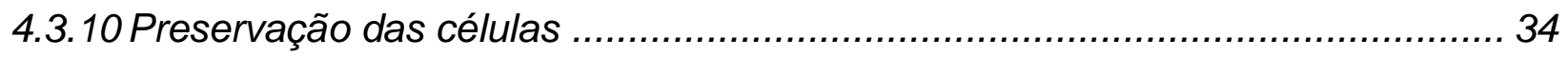

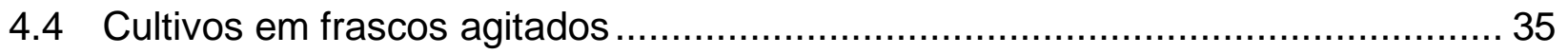

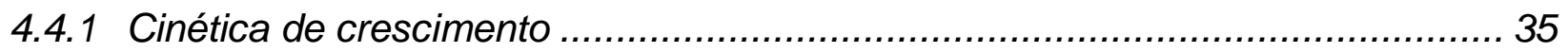

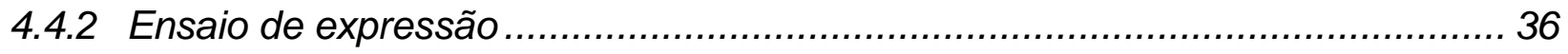




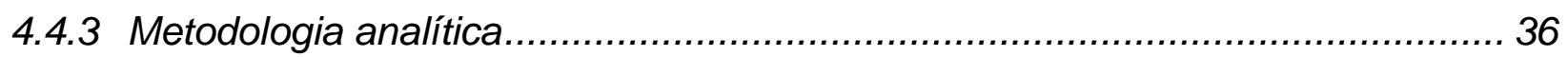

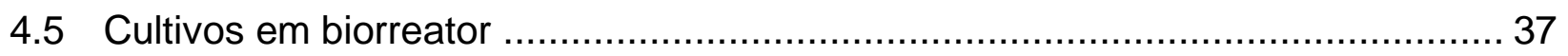

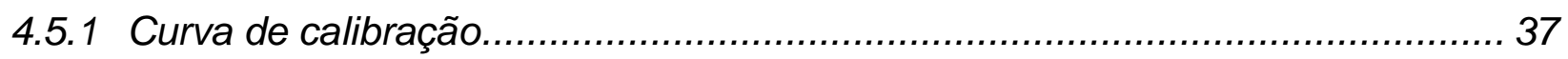

4.5.2 Determinação de parâmetros cinéticos........................................................... 38

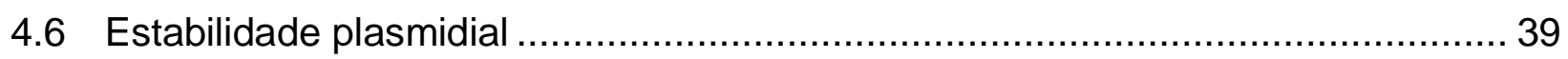

4.6.1 Avaliação da estabilidade plasmidial pela resistência ao antibiótico ................... 39

4.6.2 Número de Cópias de Plasmídeos ............................................................ 40

4.7 Determinação da concentração do indutor ..................................................... 42

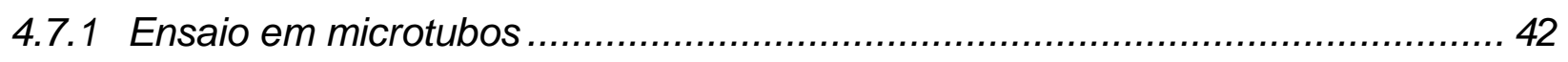

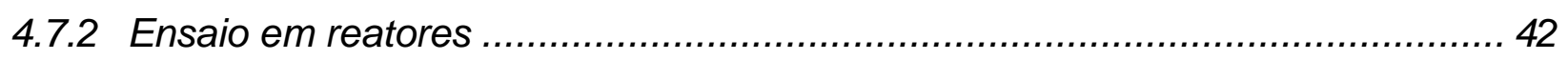

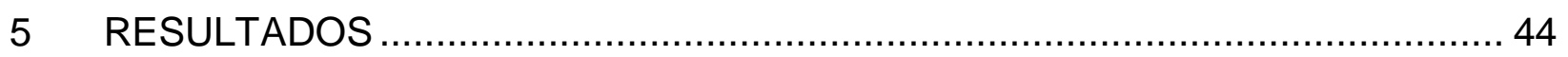

5.1 Obtenção dos sistemas de expressão ......................................................... 44

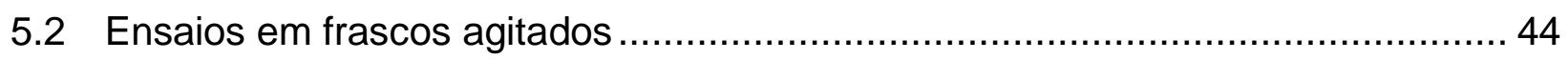

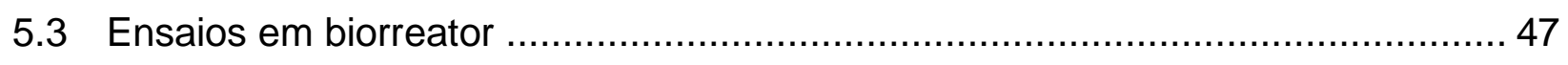

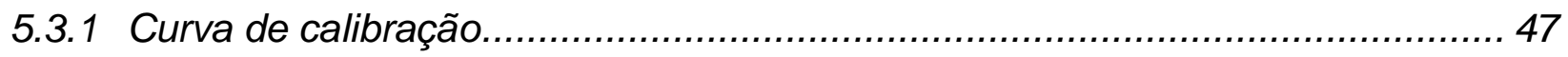

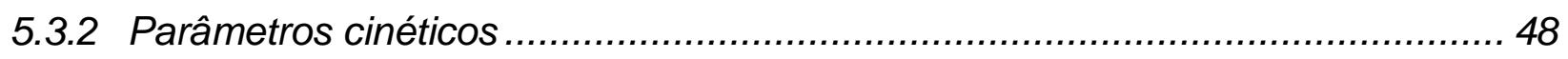

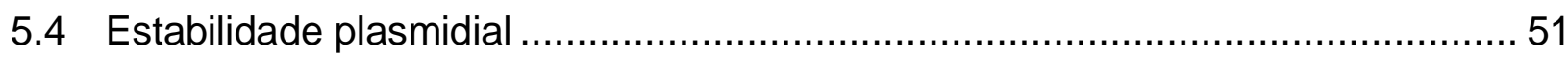

5.4.1 Avaliação da estabilidade pela resistência ao antibiótico.................................. 51

5.4.2 Número de Cópias de Plasmídeos ............................................................ 53

5.5 Determinação da concentração do indutor ...................................................... 54

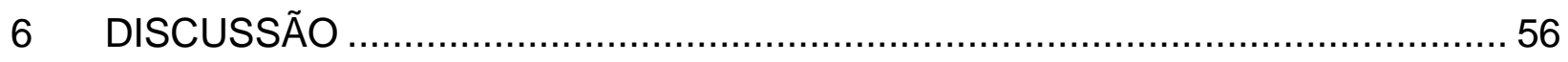

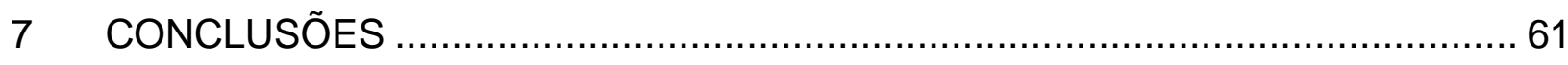

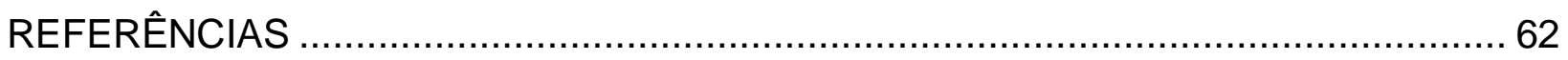




\section{INTRODUÇÃO}

O aumento no preço do petróleo, a natureza finita de combustíveis fósseis e a preocupação em relação a impactos ambientais são algumas das motivações para o grande incentivo ao desenvolvimento de biocombustíveis na substituição de combustíveis à base de petróleo, ocorrido no início do século (MUSSATTO et al., 2010). No entanto, o processo produtivo de biocombustíveis líquidos da primeira geração (como biodiesel a partir de oleaginosas e etanol a partir do caldo da cana-deaçúcar) tem levantado alguns pontos questionáveis, como a competição por terra e água usadas para produção de comida (FARGIONE et al., 2008; SEARCHINGER et al., 2008) e o alto custo de produção e processamento que necessitam subsídios governamentais. Assim, os impactos cumulativos de vários problemas têm estimulado o interesse no desenvolvimento de biocombustíveis de segunda geração, os quais são produzidos a partir de materiais lignocelulósicos. Esses materiais incluem subprodutos (palha de cereais, bagaço de cana, resíduos florestais) e resíduos (componentes orgânicos de resíduos sólidos urbanos) (SIMS et al., 2009).

$\mathrm{Na}$ produção do etanol de segunda geração, a biomassa lignocelulósica é triturada e misturada de forma a aumentar a área superficial e homogeneidade, sendo então submetida a um pré-tratamento (meio ácido e alta temperatura, "steam explosion", oxidação úmida, entre outros) de forma a destruir a parede celular, remover a lignina e expor os carboidratos poliméricos à fase líquida. Em seguida, faz-se a conversão enzimática de açúcares poliméricos em monoméricos através do uso de enzimas (principalmente celulases e hemicelulases). Os açúcares assim gerados (pentoses, C5, e hexoses, C6) podem então ser utilizados como fonte de carbono no processo de fermentação por diferentes microrganismos para a produção de etanol (HESS, 2008). Uma etapa crítica da conversão da biomassa lignocelulósica em etanol é a hidrólise enzimática, na qual diversas atividades enzimáticas são necessárias. Atualmente, as preparações comercialmente disponíveis são misturas complexas, genericamente nomeadas de "celulases", isoladas de fungos filamentosos, e conhecese muito pouco sobre a maioria destas proteínas presentes (BANERJEE et al., 2010; NAGENDRAN et al., 2009) sendo que algumas enzimas são produzidas em baixas 
concentrações ou concentrações insuficientes para suportar o processo de conversão em condições industriais. Tais proteínas são excelentes candidatas para a expressão heteróloga a fim de se poder suplementar coquetéis fúngicos. Assim, torna-se importante o desenvolvimento de plataformas de expressão heteróloga robustas capazes de produzir enzimas a baixo custo com o mínimo de limitações no que diz respeito à utilização em larga escala.

A bactéria Escherichia coli é o hospedeiro mais estudado para a produção de biomoléculas recombinantes. A principal motivação está no fato de ser um organismo bem caracterizado do ponto de vista genético, fisiológico e de expressão ( $\mathrm{CHOl}$ et al., 2006), bem como pela possibilidade de expressão em cultivo de alta densidade celular com altos níveis de produtividade (CHOI et al., 2006; LEE, 1996; SHILOACH; FASS, 2005). Estes processos necessitam do uso de construção plasmidial bacteriana como vetor carregando um gene a ser expresso e a grande maioria dos vetores de expressão contém um gene de resistência a um antibiótico como marcador seletivo (PEUBEZ et al., 2010; SZPIRER et al., 2005). Apesar de todas as conhecidas vantagens do uso da E. coli como hospedeiro, a instabilidade plasmidial e o uso do sistema de estabilização baseada em antibiótico é uma limitação conhecida pois acarreta em aumento do custo do processo e na necessidade de sua remoção do produto final e dos efluentes, além possíveis barreiras em questões regulatórias, principalmente para o caso de biomoléculas com finalidade terapêuticas.

Atualmente, com o avanço da engenharia genética, há ferramentas disponíveis para a estabilização do plasmídeo sem a necessidade do uso de antibióticos. Uma dessas ferramentas é o sistema toxina-antitoxina (TA). Este sistema está presente naturalmente em diferentes microrganismos e é frequentemente utilizado para seleção na clonagem e expressão de proteínas em células bacterianas (UNTERHOLZNER et al., 2013). Com a tecnologia de estabilização de plasmídeos livre de antibióticos, tornase interessante sua aplicação na produção de moléculas com alto rendimento e qualidade, como uma abordagem comercialmente viável (BAESHEN et al., 2015).

Sendo assim, este trabalho foi desenvolvido com o objetivo de avaliar o sistema toxina-antitoxina para estabilização plasmidial, em Escherichia coli, como forma de caracterizar uma plataforma alternativa para a produção de proteínas recombinantes. 


\section{REVISÃO DE LITERATURA}

\section{$2.1 \quad$ Escherichia coli}

A bactéria Escherichia coli é um dos hospedeiros mais utilizados para a expressão de várias proteínas recombinantes, devido à sua rápida taxa de crescimento, fácil manipulação genética e alta taxa de síntese de proteína recombinante (RODRIGUEZ et al., 2014; SAHDEV et al., 2008). E. coli foi o primeiro hospedeiro de expressão utilizado para a produção de um biofármaco: a insulina humana, cuja aprovação regulatória foi concedida em 1982 para o tratamento de diabetes (BAESHEN et al., 2015). Atualmente, cerca de 30\% das proteínas terapêuticas aprovadas utilizam esta bactéria como hospedeiro.

Tabela 1 - Exemplos de biofármacos produzidos em E.coli (adaptado de BAESHEN et al., 2015).

\begin{tabular}{lll}
\hline Biofármaco & Aplicação terapêutica & Empresa \\
\hline Humulina (insulina rh) & Diabetes & Eli Lilly \\
\hline IntronA (interferon $\alpha 2 b)$ & Câncer, hepatite, verrugas genitais & Schering-Plough \\
\hline Roferon (interferon $\alpha 2 a)$ & Leucemia & Hoffman-La Roche \\
\hline $\begin{array}{l}\text { Humatrope (hormônio de crescimento } \\
\text { rh somatropina) }\end{array}$ & Deficiência de hGH em crianças & Eli Lilly \\
\hline Neupogen (filgrastim) & Neutropenia & \\
\hline Betaferon (interferon $\beta$-1b) & Esclerose múltipla & Amgen Inc. \\
\hline Lispro (insulina de rápida ação) & Diabetes & Schering Ag \\
\hline Rapilysin (reteplase) & Enfarte do miocárdio agudo & Eli Lilly \\
\hline Infergen (interferon acon-1) & Hepatite C crônica & Roche \\
\hline Glucagon & Hipoglicemia & Amgen \\
\hline Beromun (tasonermina) & Sarcoma leve & Eli Lilly \\
\hline Ontak (denileucina difitox) & Linfoma de células T cutâneo & Boehringer Ingelheim \\
\hline $\begin{array}{l}\text { Lantus (insulina glargina de longa } \\
\text { duração) }\end{array}$ & Diabetes & Seragen Inc. \\
\hline Kineret (anakinra) & & Aventis \\
\hline Natrecor (nesiritida) & Artrite reumatoide & \\
\hline Somavert (pegvisomanto) & Insuficiência cardíaca congestiva & Amgen \\
\hline $\begin{array}{l}\text { Calcitonina (calcitonina } \\
\text { recombinante) }\end{array}$ & Acromegalia & Scios Inc. \\
\hline
\end{tabular}




\begin{tabular}{lll}
\hline Leucentis (ranibizumab) & $\begin{array}{l}\text { Degeneração macular relacionada à } \\
\text { idade }\end{array}$ & Novartis \\
\hline $\begin{array}{l}\text { Preotact (hormônio paratireoide } \\
\text { humano) }\end{array}$ & Osteoporose & Nycomed Danmark \\
\hline $\begin{array}{l}\text { Krystexxal (urato oxidase rh, } \\
\text { PEGtilado) }\end{array}$ & Gota & Savient \\
\hline Nivestim (filgrastim, rhGCSF) & Neutropenia & Hospira \\
\hline Voraxaze (glucarpidase) & $\begin{array}{l}\text { Redução do nível tóxico da concentração } \\
\text { de metotrexato em pacientes com função } \\
\text { renal reduzida }\end{array}$ & BTG International \\
& Osteoporose, hipoparatireoidismo & NPS Pharmaceuticals \\
\hline Preos (hormônio paratireoide) & & \\
\hline
\end{tabular}

Apesar de todas as conhecidas vantagens do uso de E. coli como hospedeiro comparado a outros sistemas de expressão, alguns inconvenientes precisam ser considerados, como a instabilidade do mRNA, a presença de códons raros em proteínas heterólogas (podendo gerar erro na tradução) (BAESHEN et al, 2015), a expressão da proteína de interesse ser, em geral, intracelular, o que pode acarretar em enovelamento inadequado e/ou a obtenção da proteína na forma insolúvel e inativa. Além disso, E. coli não contém as ferramentas genéticas necessárias para a realização de modificações pós-traducionais, como por exemplo a glicosilação e metilação. Por fim, o cultivo é normalmente feito sob a necessidade do uso de antibiótico a fim de se promover uma pressão seletiva para a manutenção plasmidial ( $\mathrm{CHOl}$ et al., 2006).

\subsection{Estabilidade plasmidial}

Para a expressão da proteína heteróloga de interesse, é realizada a etapa de clonagem, na qual a sequência de DNA que codifica a proteína é inserida em um vetor, no caso um plasmídeo. O DNA plasmidial, no entanto, além de não ser essencial ao hospedeiro, torna-se um elemento de gasto energético a cada replicação. Portanto, para aliviar a carga metabólica, a bactéria acaba eliminando o plasmídeo. No entanto, ao eliminar o DNA plasmidial, as células-filhas geradas não o receberão também e, seguindo um crescimento exponencial de gerações de células-filhas ausentes deste DNA, o rendimento do processo irá diminuir consideravelmente. Assim, a estabilidade plasmidial é uma das questões críticas na produção de proteínas recombinantes 
(GUPTA et al., 1995), uma vez que a expressão da proteína de interesse está condicionada à manutenção do plasmídeo na célula.

Há duas maneiras de se caracterizar a estabilidade plasmidial: estrutural e segregacionista. A estrutural está relacionada à sequência do DNA. Portanto, a instabilidade estrutural compreende alterações como inserções, deleções e rearranjos de nucleotídeos na sequência do plasmídeo. Já a instabilidade segregacionista referese à sua perda durante a divisão celular, resultando em uma célula-filha sem o plasmídeo (FRIEHS, 2004).

A utilização da expressão "instabilidade plasmidial" na maioria das vezes se refere à segregação plasmidial. A replicação correta dos plasmídeos durante a divisão celular é um problema central em sistemas recombinantes. Como a taxa de crescimento específico de células sem plasmídeo é maior comparada às células com plasmídeo, a presença de células sem o plasmídeo no início de um cultivo poderá se tornar dominante ao fim, afetando drasticamente a produtividade da proteína recombinante (FRIEHS, 2004). Muitos fatores podem influenciar a estabilidade plasmidial, como a taxa de crescimento celular, o tamanho do inserto e do plasmídeo, o número de cópias, a toxicidade da proteína expressa, e até mesmo condições de cultivo ( $\mathrm{pH}$, temperatura, modo de operação, oxigênio dissolvido) (CHENG et al., 2003; FRIEHS, 2004; GUPTA et al., 1995).

Para a produção de proteínas recombinantes, vetores de expressão foram desenvolvidos contendo genes de resistência a antibióticos como marcadores seletivos e para a manutenção do plasmídeo na célula. No entanto, antibióticos são compostos muito caros, inviabilizando sua utilização nos processos caracterizados pelo baixo custo do produto e grande volume de produção, além da possibilidade de contaminação do produto final. No caso de proteínas terapêuticas, a contaminação com antibiótico é inaceitável do ponto de vista industrial, médico e regulatório, sendo necessária a purificação do produto final e efluente, para a remoção de possíveis resíduos do antibiótico utilizado no processo (SZPIRER; MILINKOVITCH, 2005). Na questão regulatória, além do contexto de finalidade do produto final, a aceitabilidade destes marcadores é também dependente do antibiótico. A canamicina e a tetraciclina (em uma extensão menor) são ainda aceitas pelas autoridades de saúde. No entanto, o 
uso de $\beta$-lactâmicos muitas vezes está associado a respostas alérgicas e é estritamente proibido (PEUBEZ et al., 2010). Os crescentes requerimentos regulatórios aos quais agentes biológicos estão sujeitos terão um grande impacto no campo da expressão e produção industrial de proteínas. Há uma expectativa de que, num futuro próximo, haja "tolerância zero" em relação aos sistemas de produção e seleção baseados em antibióticos (SODOYER et al., 2012).

Além dos problemas do alto custo e de riscos de contaminação, em condições de cultura intensiva (alta densidade celular e/ou cultivo contínuo) o uso de antibióticos torna-se menos eficiente devido à diluição ou inativação do antibiótico (BANEYX, 1999).

\subsection{Sistema toxina-antitoxina}

Sistemas toxina-antitoxina (TA) são pequenos elementos genéticos compostos de um gene que codifica uma proteína tóxica e sua antitoxina correspondente, que regulam o metabolismo e viabilidade da célula em bactérias e arqueas (ROCKER; MEINHART, 2016). As toxinas de todos os sistemas TA conhecidos são proteínas, enquanto que as antitoxinas podem ser tanto proteínas como RNAs não codificantes (YAMAGUCHI et al., 2011). Os sistemas TA são classificados baseados na natureza molecular da antitoxina e seu modo de interação com a toxina. No tipo I e III as antitoxinas são pequenos RNAs não codificantes, enquanto que nas outras classes as antitoxinas são pequenas proteínas. No tipo I, a expressão do gene da toxina é regulada por um RNA anti-senso transcrito do gene da toxina, mas na orientação reversa. Ou seja, a antitoxina é um pequeno RNA complementar a um trecho do mRNA da toxina que, quando ligadas, formam uma molécula de dupla fita que estimula a degradação do mRNA (FOZO et al., 2009). Na classe II, tanto a toxina como a antitoxina são traduzidos em proteínas. A antitoxina forma um complexo polipeptídico com a toxina para inibir a toxicidade e para autorregular o módulo TA. A toxina, quando liberada do complexo TA ataca o alvo celular, levando à interrupção do crescimento e eventual morte celular (YAMAGUCHI et al., 2011). No tipo III, a antitoxina é um mRNA, o qual inibe diretamente a toxicidade da proteína tóxica expressa (FINERAN et al., 
2009). Alguns autores, como Unterholzner et al. (2013), Masuda et al. (2012) e Wang et al. (2012) defendem a existência de outras duas classes, tipo IV e tipo V. Nestas últimas no entanto, a toxina e a antitoxina não interagem diretamente como ocorre nos outros 3 casos descritos, seja ao nível de RNA ou proteína, e, portanto, não são considerados casos de sistema TA por alguns pesquisadores.

Em geral, a toxina é mais estável que a antitoxina, mas a antitoxina é expressa em maior quantidade. Se o fornecimento da antitoxina é interrompido, como em condições especiais de crescimento ou por perda de plasmídeo (no caso de sistemas TA em plasmídeos), a antitoxina é rapidamente degradada e pode não mais reprimir a toxina. Consequentemente, a toxina se torna ativa e pode atuar nos alvos celulares. Tipicamente, toxinas TA atuam em processos celulares cruciais tais como tradução, replicação, formação do citoesqueleto, integridade da membrana e biossíntese da parede celular. Sistemas TA e seus componentes são também ferramentas versáteis para diferentes aplicações na pesquisa básica e biotecnologia. Atualmente, sistemas TA são frequentemente usados para a seleção em clonagem e expressão de proteínas em células bacterianas (UNTERHOLZNER et al., 2013).

O primeiro sistema TA descoberto, $\operatorname{ccdA} / \mathrm{ccdB}$, foi descoberto em 1983 e descrito como operons bicistrônicos que garantiam a manutenção de plasmídeos estáveis em bactérias (OGURA; HIRAGA, 1983). O sistema faz parte da classe de módulos TA mais bem estudados e abundantes - Tipo II (UNTERHOLZNER et al., 2013). Uma vez que a toxina e antitoxina são ligadas uma à outra, um complexo neutro proteína-proteína é formado em condições de não-estresse, que se mantém inativo no citoplasma da célula. Concentrações celulares de complexos TA tipo II são geralmente autorregulados a nível transcricional pela antitoxina ou pelo complexo toxina-antitoxina (GERDES; MAISONNEUVE, 2012). A antitoxina mantém o gene da toxina reprimido, cuja ativação é realizada pela degradação da antitoxina por proteases (Clp ou Lon), liberando a toxina (SCHUSTER; BERTRAM, 2013).

Os sistemas tipo II foram agrupados em 12 diferentes famílias, dependendo da sequência primária e atividade da toxina. Eles interferem, por exemplo, na replicação e transcrição por inibir topoisomerases (BERNARD; COURIER, 1992, MAKI et al., 1992) ou na replicação desemparelhada através da interação com o grampo de deslizamento 
beta da DNA polimerase III (AAKRE et al., 2013). O sistema TA $c c d A / c c d B$ do plasmídeo $\mathrm{F}$ é composto por uma antitoxina instável $\mathrm{Ccd} \mathrm{A}_{\mathrm{F}}$, de cerca de 90 aminoácidos, que é degradada pela protease ATP-dependente Lon (VAN MELDEREN et al., 1994, 1996), e pela toxina estável $\mathrm{CcdB}_{\mathrm{F}}$, composta por cerca de 100 aminoácidos. Ambos $\mathrm{CcdA}_{\mathrm{F}}$ e $\mathrm{CcdB} \mathrm{B}_{\mathrm{F}}$ são necessários para autorregulação (AFIF et al., 2001). A toxina $C_{c d B} B_{F}$ tem como alvo a DNA girase, levando à inibição da replicação $e$ transcrição, passando para a indução do sistema SOS e, por último, à morte celular (BERNARD; COUTURIER, 1992, BERNARD et al., 1993).

Baseado neste sistema, $c c d A / c c d B$, foi desenvolvida uma tecnologia aplicada à expressão heteróloga de proteínas num sistema de estabilização independente de antibiótico. Este sistema foi proposto por Szpirer e Milinkovitch (2005) e é comercializado pela Delphi Genetics (Delphi Genetics S.A., Gosselies, Charleroi, Bélgica). O gene $c c d B$, que codifica a proteína tóxica $\mathrm{CcdB}$, é inserido no cromossomo do microrganismo e é expresso constitutivamente. O gene ccdA é introduzido no plasmídeo, sob o controle do promotor constitutivo mob, atuando como um repressor do promotor do gene ccdB. (Figura 1) (SODOYER et al., 2012).

Szpirer e Milinkovitch (2005) demonstraram que usando este sistema, após 20 gerações em um meio não-seletivo, 100\% das bactérias ainda continham o plasmídeo. Duas horas após indução, o plasmídeo ainda estava presente em todas as células, o que não é o caso em um sistema padrão pET/BL21(DE3) em meio não-seletivo (SODOYER et al., 2012). O gene da proteína tóxica $c c d B$, expresso constitutivamente pela célula, já tem sido utilizado em tecnologias de clonagem para a seleção de recombinantes e hoje é utilizado como um componente essencial de várias ferramentas e kits de clonagem molecular, como o Gateway® Technology (Invitrogen, Carlsbad, CA, EUA) (SZPIRER; MILINKOVITCH, 2005). 


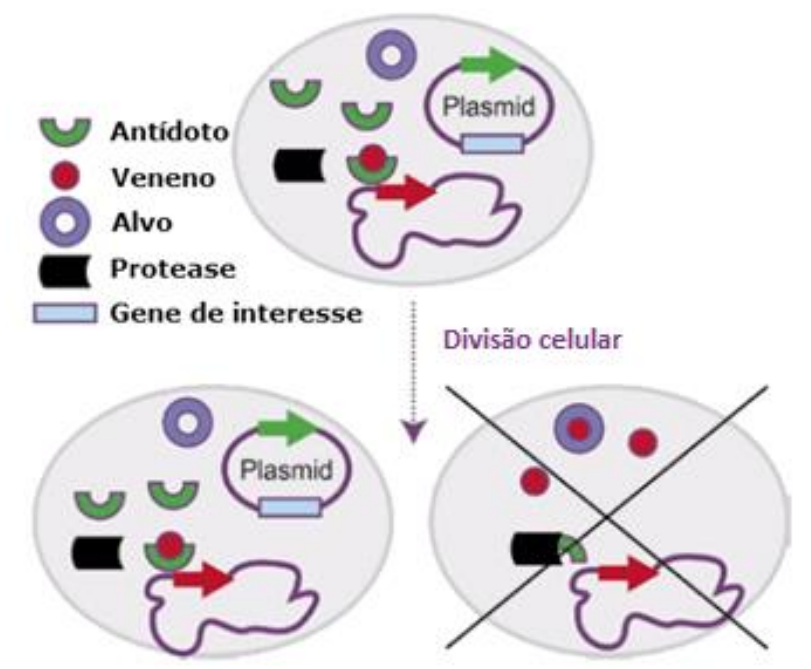

Figura 1 - Princípio do sistema toxina-antitoxina. Adaptado de Szpirer e Milinkovitch, 2005.

\subsection{Suplementação de coquetéis enzimáticos para hidrólise de material lignocelulósico}

O conhecimento da composição química dos materiais lignocelulósicos é um fator-chave para a eficiência da produção de biocombustíveis durante os processos de conversão. A sua estrutura é composta basicamente de três macromoléculas: celulose, hemicelulose e lignina, cujas proporções podem variar devido às influências genéticas e ambientais e suas interações (BALAT, 2010).

Devido à complexidade e recalcitrância destes materiais, uma variedade de atividades enzimáticas é necessária para a conversão de biomassa lignocelulósica a produtos fermentescíveis. Atividades essenciais conhecidas para degradar a celulose cristalina incluem endo- $\beta$-1,4-glucanases, exo- $\beta$-1,4-glucanases e $\beta$-glucosidases (VAN DYK; PLETSCHKE, 2012). Uma maior variedade de enzimas é necessária para a despolimerização da hemicelulose, incluindo endo- $\beta$-1,4-xilanases, $\beta$-xilosidases, $\alpha$ arabinosidases, $\alpha$-glucoronidases e esterases (BANERJEE et al., 2010). Além das celulases e hemicelulases, outras proteínas acessórias exercem um papel importante para a completa degradação dos componentes lignocelulósicos (ALVIRA et al.,2011), como é o caso das expansinas, que rompem as ligações de hidrogênio entre as microfibrilas de celulose ou entre celulose e outros componentes por um mecanismo 
ainda desconhecido, causando afrouxamento da fibra e, consequentemente, maior acessibilidade das enzimas (SALOHEIMO et al., 2002).

A fim de se obter coquetéis balanceados e feitos sob medida para a biomassa a ser hidrolisada é fundamental a identificação da composição mínima essencial de enzimas e da razão mássica entre estas, o que permitiria então a montagem racional de coquetéis com a possibilidade de redução de custos do processo de produção e de conversão da biomassa (MEYER et al., 2009). Uma estratégia é a construção de novo das misturas enzimáticas, na qual diferentes enzimas são produzidas e purificadas individualmente, e uma montagem racional é realizada (BANERJEE et al., 2010). Outra possível abordagem é a suplementação de coquetéis enzimáticos, como realizado por Alvira e colaboradores (2011), onde foi avaliado o efeito da suplementação de coquetéis comerciais com endoxilanase e $\alpha$-L-arabinofuranosidase, produzidas em sistemas heterólogos.

Visando à suplementação de coquetéis enzimáticos, foram selecionadas como modelo para o estudo as proteínas $\beta$-1,3-1,4-glucanase (EC 3.2.1.73), uma celulase endoglucanase de cerca de $55 \mathrm{kDa}$ da família das glicosil hidrolases (GH5), e uma expansina, proteína acessória da família EXLX1. A endoglucanase é responsável pela hidrólise de ligações $\beta$-1,3-1,4-D-glicosídicas entre moléculas de $\beta$-D-glucanas. A expansina é uma proteína em torno de $23 \mathrm{kDa}$ que possui atividades de relaxamento e expansão em fibras de paredes celulares vegetais, auxiliando o acesso de enzimas à estrutura dos materiais lignocelulósicos. 


\section{OBJETIVOS}

O trabalho foi desenvolvido com o objetivo de avaliar o sistema toxina-antitoxina para estabilização plasmidial independente de antibiótico, em Escherichia coli, como forma de caracterizar uma plataforma alternativa para a produção de proteínas recombinantes para suplementação de coquetéis enzimáticos.

Durante o estudo, foi avaliado o sistema de estabilização plasmidial toxinaantitoxina, utilizando a linhagem SE1, em comparação com o sistema tradicional pET, o qual utiliza antibióticos como marcador seletivo, utilizando a linhagem BL21(DE3). Para ambas as linhagens, a síntese das proteínas $\beta-1,3-1,4-$ glucanase e expansina foi avaliada, totalizando quatro construções no presente trabalho. 


\section{MATERIAL E MÉTODOS}

O trabalho foi desenvolvido no Laboratório de Biossíntese de Hidrolases Bacterianas (LBHB), situado no Laboratório Nacional de Ciência e Tecnologia do Bioetanol (CTBE-Campinas), em parceria com a pesquisadora Dra. Sindelia Freitas Azzoni.

\subsection{Microrganismos e plasmídeos}

Foram utilizadas as linhagens de E.coli DH5a (para clonagem) e BL21(DE3) (Novagen, Merck Millipore, Billerica, MA, EUA), com o vetor pET-28a-c(+) (Novagen), o qual possui gene de resistência à canamicina, contendo os genes de $\beta$-1,3-1,4glucanase (1432 bp), que é uma celulase da família das glicosil hidrolases (GH5), e expansina, proteína acessória da família EXLX1 (624bp), ambas de Bacillus subtilis. Estes vetores foram nomeados end/pET28a e exp/pET28a, respectivamente. As linhagens foram gentilmente cedidas pelo Dr. Roberto Ruller (Laboratório de Biologia Molecular, Laboratório Nacional de Ciência e Tecnologia do Bioetanol - CTBE, Campinas).

Para a construção dos sistemas de expressão com sistema toxina-antitoxina (TA), foi utilizado o kit StabyExpress T7 (Delphi Genetics), o qual fornece células de clonagem CYS21 (derivadas da linhagem de E. coli DH10B) e de expressão SE1 (derivadas da E. coli $\mathrm{BL21}(\mathrm{DE} 3)$ ), ambas contendo o gene da toxina $\mathrm{CcdB}_{\mathrm{F}}$ no genoma. As células foram fornecidas já competentes comercialmente. $O$ kit fornece também 0 plasmídeo pStaby, contendo o gene da antitoxina $\mathrm{Ccd}_{\mathrm{F}}$, e que, por ser proveniente de um pET-21a (+), possui o gene de resistência ao antibiótico ampicilina.

Os plasmídeos citados, provenientes do sistema pET (plasmid for Expression by T7 RNA polymerase) (Novagen), possuem a expressão regulada pelo promotor do fago T7. A indução ocorre pela adição de Isopropil- $\beta$-D-tiogalactopiranosídeo (IPTG), liberando o repressor $\mathrm{Lacl}$ do operador lac que controla a síntese da T7 RNA polimerase presente no profago DE3 inserido no genoma da célula hospedeira. Dessa 
forma, a T7 RNA polimerase é capaz de transcrever o gene heterólogo presente no plasmídeo sob controle do promotor T7.

\subsection{Meios de cultivo}

Para as etapas de clonagem, foi utilizado o meio complexo LB (Luria Bertani): 5 $\mathrm{g} / \mathrm{L}$ de extrato de levedura, $10 \mathrm{~g} / \mathrm{L}$ de cloreto de sódio e $10 \mathrm{~g} / \mathrm{L}$ de triptona. Para meio LB solidificado, foi acrescentado ágar a 1,5\%.

Para a preservação das células, foi utilizado meio mínimo definido M9, contendo, por litro, $6 \mathrm{~g}$ de $\mathrm{Na}_{2} \mathrm{HPO}_{4}, 3 \mathrm{~g}$ de $\mathrm{KH}_{2} \mathrm{PO}_{4}, 0,5 \mathrm{~g}$ de $\mathrm{NaCl}, 1 \mathrm{~g}$ de $\mathrm{NH}_{4} \mathrm{Cl}, 1 \mathrm{mmol}$ de $\mathrm{MgSO}_{4}, 100 \mu \mathrm{mol}$ de $\mathrm{CaCl}_{2}, 3 \mathrm{nmol}$ de $\left(\mathrm{NH}_{4}\right)_{6} \mathrm{Mo}_{7} \mathrm{O}_{24} .4 \mathrm{H}_{2} \mathrm{O}, 0,4 \mu \mathrm{mol}$ de $\mathrm{H}_{3} \mathrm{BO}_{3}, 30$ nmol de $\mathrm{CoCL}_{2} .6 \mathrm{H}_{2} \mathrm{O}, 10 \mathrm{nmol}$ de $\mathrm{CuSO}_{4} .5 \mathrm{H}_{2} \mathrm{O}, 80 \mathrm{nmol}$ de $\mathrm{MnCl}_{2} .4 \mathrm{H}_{2} \mathrm{O}, 10 \mathrm{nmol}$ de $\mathrm{ZnSO}_{4} .7 \mathrm{H}_{2} \mathrm{O}$ e $10 \mathrm{nmol}$ de $\mathrm{FeSO}_{4} .7 \mathrm{H}_{2} \mathrm{O}$ e $2 \mathrm{~g}$ de glucose.

Para os cultivos, foi utilizado o meio definido HDF, contendo, por litro, 13,3 g de $\mathrm{KH}_{2} \mathrm{PO}_{4}, 4,0 \mathrm{~g}$ de $\left(\mathrm{NH}_{4}\right)_{2} \mathrm{HPO}_{4}, 1,2 \mathrm{~g}$ de $\mathrm{MgSO}_{4} .7 \mathrm{H}_{2} \mathrm{O}, 1,7 \mathrm{~g}$ de ácido cítrico, 14,1 $\mathrm{mg}$ de EDTA, $1 \mathrm{~mL}$ de solução de elementos traço, 100,8 mg de citrato de ferro III e $45 \mathrm{mg}$ de tiamina. A solução de elementos traços continha $2,5 \mathrm{~g} / \mathrm{L}$ de $\mathrm{CoCl}_{2} \cdot 6 \mathrm{H}_{2} \mathrm{O}, 15 \mathrm{~g} / \mathrm{L}$ de $\mathrm{MnCl}_{2} .4 \mathrm{H}_{2} \mathrm{O}, 1,5 \mathrm{~g} / \mathrm{L}$ de $\mathrm{CuCl}_{2} .2 \mathrm{H}_{2} \mathrm{O}, 3 \mathrm{~g} / \mathrm{L}$ de $\mathrm{H}_{3} \mathrm{BO}_{3}, 2,1 \mathrm{~g} / \mathrm{L}$ de $\mathrm{Na}_{2} \mathrm{MoO}_{4} .2 \mathrm{H}_{2} \mathrm{O}$ e 33,8 $\mathrm{g} / \mathrm{L}$ de $\mathrm{Zn}\left(\mathrm{CH}_{3} \mathrm{COO}\right)_{2.2} 2 \mathrm{H}_{2} \mathrm{O}$.

\subsection{Obtenção do sistema de expressão}

Para obter células de Escherichia coli para expressão das proteínas endoglucanase e expansina utilizando o sistema TA para estabilização do plasmídeo, foi adotada a estratégia de inserção do cassete do gene da antitoxina $c c d A$, a partir do pStaby, no vetor contendo os genes das proteínas de interesse, construídos em pET28a-c(+) (Figura 2). O cassete da antitoxina é composto pelo gene $c c d A$ e pelo promotor mob. Dessa forma, a proteína é regulada por tal promotor, sendo expressa constitutivamente. 


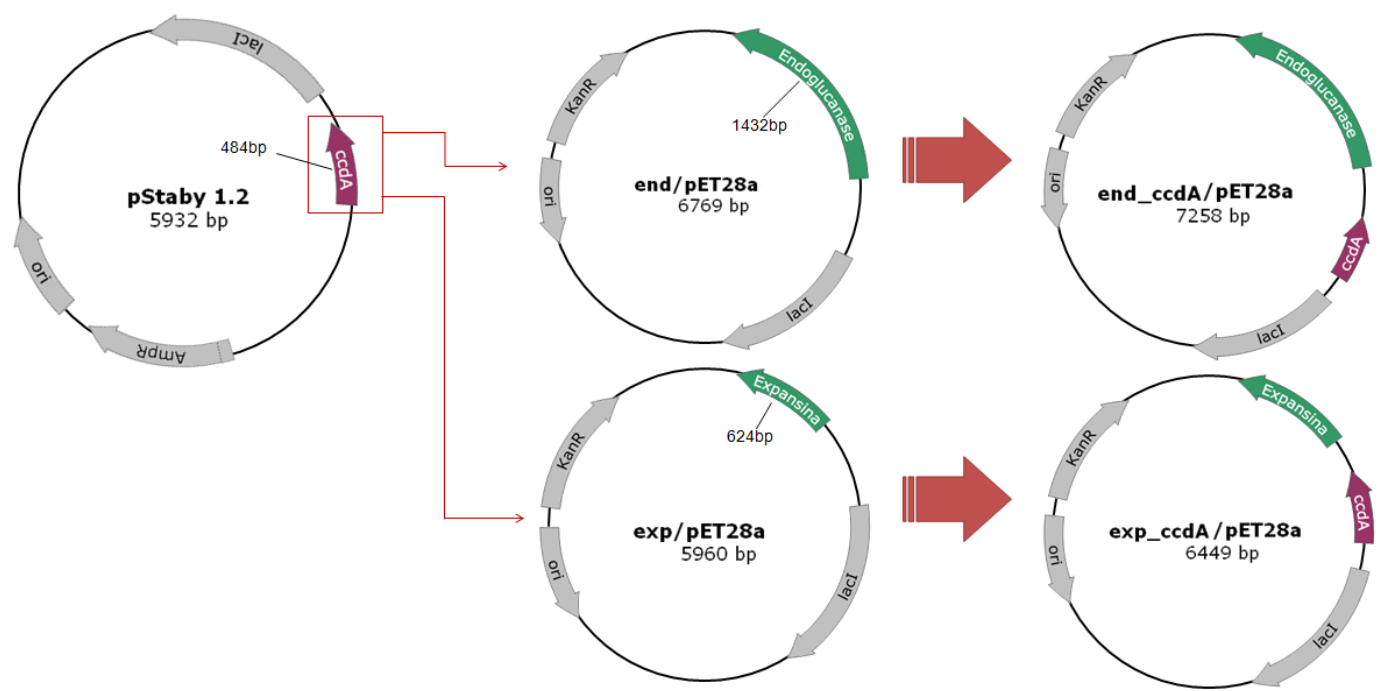

Figura 2 - Estratégia de subclonagem do cassete ccdA no plasmídeo pET28a(+) contendo os genes de $\beta-1,3-1,4$-glucanase e expansina.

O cassete de expressão da antitoxina $c c d A$ (484 pb), presente no plasmídeo pStaby (Delphi Genetics), está inserido entre os sítios da enzima de restrição Sphl (GCTTGC) (Figura 3). Portanto, para obter o cassete, o plasmídeo foi digerido com a enzima de restrição citada e, da mesma forma, os vetores construídos em pET-28a$c(+)$ foram digeridos com a mesma enzima para possibilitar a inserção do gene.

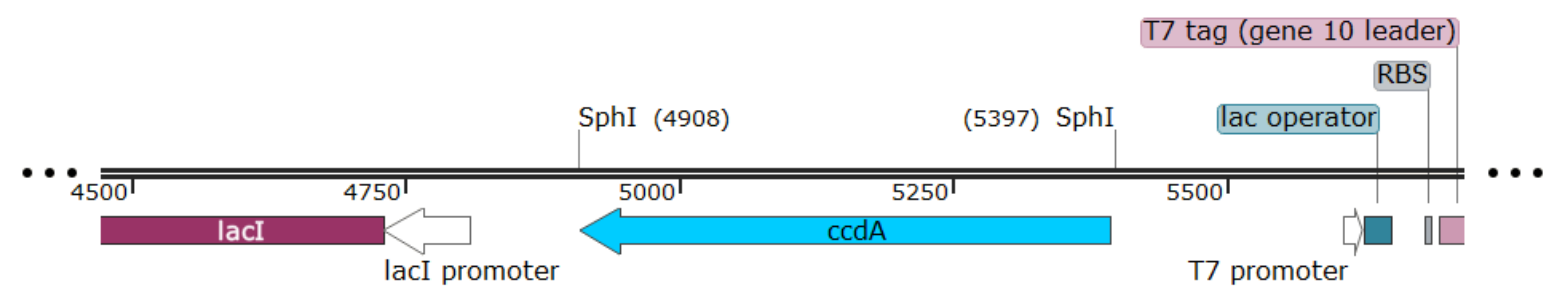

$\underset{5932 \text { bp }}{\text { pStaby }} \mathbf{1 . 2}$

Figura 3 - Trecho do plasmídeo pStaby, evidenciando a localização do cassete ccdA entre os sítios da enzima de restrição Sphl.

\subsubsection{Transformação em $\mathrm{DH} 5 \alpha$}

O plasmídeo pStaby foi inserido na célula de clonagem E. coli DH5a quimicamente competente obtidas comercialmente. Aproximadamente $100 \mathrm{ng}$ de 
plasmídeo foram adicionados a $100 \mu \mathrm{L}$ de células competentes. Após 30 minutos em banho de gelo, foi realizado o choque térmico, passando por 50 segundos a $42{ }^{\circ} \mathrm{C}$, seguido de 2 minutos no gelo. Em seguida, foram adicionados $600 \mu \mathrm{L}$ de meio LB e colocados a $37^{\circ} \mathrm{C}$, sob agitação de $200 \mathrm{rpm}$ por 1 hora. Por fim, as bactérias foram plaqueadas em meio LB solidificado, contendo $100 \mathrm{mg} / \mathrm{L}$ de ampicilina. As placas foram deixadas em estufa a $37^{\circ} \mathrm{C}$ overnight para obtenção das células transformadas.

\subsubsection{Extração do DNA plasmidial (miniprep)}

Para a subclonagem, foi necessária a extração dos plasmídeos pStaby, end/pET28a e exp/pET28a das células DH5a. Uma colônia de E. coli DH5a contendo o plasmídeo de interesse foi transferida a $10 \mathrm{~mL}$ de meio $\mathrm{LB}$, contendo $30 \mathrm{mg} / \mathrm{L}$ de sulfato de canamicina (para células com end/pET28a e exp/pET28a) e $100 \mathrm{mg} / \mathrm{L}$ de ampicilina (para células com pSTaby), e colocada a $37^{\circ} \mathrm{C}$ sob agitação de $250 \mathrm{rpm}$ overnight. Em seguida, foi realizada a extração do DNA plasmidial (miniprep) com o kit Invisorb Spin Plasmid Mini Two (Invitek Inc., Hayward, CA, EUA), seguindo o protocolo do fabricante. A quantificação do produto extraído foi realizada por espectrofotometria através do espectrofotômetro NanoDrop 2000c (Thermo Scientific, Thermo Fisher Scientific Inc., Waltham, MA, EUA). A verificação do tamanho do plasmídeo extraído foi realizada por eletroforese em gel de agarose $1 \%$.

\subsubsection{Digestão dos plasmídeos com enzima de restrição}

As reações de digestão dos plasmídeos foram conduzidas nas seguintes condições:

- $3 \mu \mathrm{g}$ de DNA plasmidial

- Tampão B (Thermo Scientific)

- 15 U de SphI (Thermo Scientific)

A mistura foi incubada em banho termostático e $37{ }^{\circ} \mathrm{C}$ por 3 horas e, em seguida, a reação foi interrompida com inativação a $65^{\circ} \mathrm{C}$ por 20 minutos. 


\subsubsection{Desfosforilação dos vetores}

Após a digestão, os vetores end/pET28a e exp/pET28a foram desfosforilados com a adição de $10 \mathrm{U}$ de CIP (Calf Intestinal Alkaline Phosphatase) e incubados a 40 ${ }^{\circ} \mathrm{C}$ por 1 hora. Em seguida, a reação foi cessada submetendo-a a $70{ }^{\circ} \mathrm{C}$ por 10 minutos.

\subsubsection{Purificação do produto digerido}

Os produtos da digestão e desfosforilação foram aplicados em gel de agarose a $1 \%$ para separação por eletroforese. Foi utilizado o padrão de peso molecular GeneRuler $1 \mathrm{~kb}$ Plus DNA Ladder (Thermo Scientific). A banda correspondente ao fragmento com o tamanho esperado foi eluído do gel e purificado utilizando o kit de extração de DNA GeneJet Gel Extraction Kit (Life Technologies, Thermo Fisher Scientific Inc., Waltham, MA, EUA), seguindo o protocolo do fabricante. O DNA purificado foi quantificado por espectrofotometria, com o equipamento NanoDrop 2000c (Thermo Scientific, EUA).

\subsubsection{Reação de ligação}

Para a inserção do cassete da antitoxina ccdA nos plasmídeos end/pET28a e exp/pET28a, estes foram submetidos à reação de ligação, considerando a equação (1) para determinação da quantidade de inserto $(c c d A)$ a ser adicionada na reação, sendo " $m$ " a massa do fragmento, em nanogramas e " $s$ " o tamanho do fragmento, em pares de bases.

$$
m_{\text {inserto }}=\frac{m_{\text {vetor }} \times s_{\text {inserto }}}{s_{\text {vetor }}} \times 3
$$

Foram utilizados $100 \mathrm{ng}$ de vetor (end/pET28a e exp/pET28a), tampão de T4 DNA ligase e 7,5 U Weiss de T4 DNA ligase (Fermentas, Thermo Fisher Scientific Inc., Waltham, MA, EUA). As reações foram incubadas em banho termostático overnight (cerca de 16 horas) a $16^{\circ} \mathrm{C}$. 


\subsubsection{Transformação em CYS21}

Após a reação de ligação, os produtos foram inseridos em células CYS21 eletrocompententes obtidas comercialmente. $\mathrm{O}$ volume de $7 \mu \mathrm{L}$ da reação de ligação foi adicionado a células CYS21 eletrocompetentes provenientes do kit StabyExpress T7 (Delphi Genetics). A eletroporação foi realizada segundo as condições preestabelecidas do eletroporador Multiporador (Eppendorf Inc., Hamburgo, Alemanha), a 2,5 kV, $25 \mu \mathrm{F}, 200$ ohms. Em seguida, foram adicionados $500 \mu \mathrm{L}$ do meio de regeneração e incubado a $37^{\circ} \mathrm{C}, 200 \mathrm{rpm}$ por 1 hora. $\mathrm{O}$ conteúdo foi plaqueado em meio LB solidificado contendo canamicina a $30 \mathrm{mg} / \mathrm{L}$ e incubado em estufa a $37^{\circ} \mathrm{C}$ por aproximadamente 16 horas.

\subsubsection{Confirmação da Subclonagem}

Para a confirmação da subclonagem, foram realizadas reações de PCR de colônia com colônias de CYS21 que cresceram após a transformação, confirmando a presença do cassete $c c d A$ e das proteínas $\beta-1,3-1,4$-glucanase e expansina. Para isto, foram sintetizados oligonucleotídeos específicos para cada cassete (Tabela 2). As reações de $\mathrm{PCR}$ foram montadas em $10 \mu \mathrm{L}$ de volume final, com a seguinte composição:

- tampão

- 0,5 $\mu \mathrm{L}$ de $\mathrm{MgCl}_{2} 25 \mathrm{mM}$

- $1 \mu \mathrm{L}$ de dNTPs a $1 \mathrm{mM}$

- 0,4 $\mu \mathrm{L}$ de cada oligonucleotídeo a $10 \mathrm{pmol} / \mu \mathrm{L}$

- 0,2 $\mu \mathrm{L}$ de Taq DNA polimerase

- $\mathrm{H}_{2} \mathrm{O}$ q.s.p. $10 \mu \mathrm{L}$

Reação:

- $94{ }^{\circ} \mathrm{C} 1$ minuto

- 30 ciclos: $94^{\circ} \mathrm{C}$ por 1 minuto $+55^{\circ} \mathrm{C}$ por 30 segundos $+72{ }^{\circ} \mathrm{C}$ por 1 minuto

$-72{ }^{\circ} \mathrm{C}$ por 3 minutos 
O produto das reações foi então aplicado em gel de agarose $1 \%$ para visualização da amplificação dos insertos por eletroforese.

Tabela 2 - Oligonucleotídeos utilizados na reação de PCR para confirmação da presença do gene da endoglucanase, expansina e do cassete ccdA.

\begin{tabular}{ll}
\hline Oligonucleotídeo & Sequência \\
\hline ccdAF & 5' - GAGCATGCGTTGTCCACGTTGTCCACGGGCCGAGCG - 3' \\
ccdAR & 5' - CCGCATGCTCACCAGTCCCTGTTCTCG - 3' \\
endFBamHI & 5' - TATATAGGATCCGCAGCAGGGACAAAAACGCC - 3' \\
endRXhol & 5' - ATATATCTCGAGATTTGGTTCTGTTCCCCAAA - 3' \\
expF & 5' - TATATACCATGGCATATGACGACCTGCATGAA - 3' \\
expR & 5' - ATATATCTCGAGTTCAGGAAACTGAACATGGC - 3' \\
\hline
\end{tabular}

Após confirmação da presença dos cassetes ccdA e dos genes de endoglucanase e expansina nos plasmídeos, então nomeados end_ccdA/pET28a e exp_ccdA/pET28a, foi realizada a extração dos plasmídeos das células de clonagem utilizando o kit Invisorb Spin Plasmid Mini Two (Invitek), de acordo com o protocolo do fabricante.

\subsubsection{Transformação de células E. coli de expressão SE1}

Células Escherichia coli de expressão SE1 eletrocompetentes foram transformadas, seguindo o protocolo já citado anteriormente, com os plasmídeos end_ccdA/pET28a e exp_ccdA/pET28a. Após plaqueamento em meio LB solidificado, contendo $30 \mathrm{mg} / \mathrm{L}$ de sulfato de canamicina, e verificação de colônias positivas por PCR, foi criado um banco de trabalho, estocado a $-80^{\circ} \mathrm{C}$.

\subsubsection{Preservação das células}

Após a confirmação da presença do cassete de ccdA e dos genes de endoglucanase e expansina, foi criado um banco de células master. A partir de uma colônia positiva, confirmada por PCR, foi crescido um inóculo em $10 \mathrm{~mL}$ de meio LB. No dia seguinte, a absorbância $(600 \mathrm{~nm})$ do inóculo foi medida e $100 \mathrm{~mL}$ de meio $\mathrm{M9}$ foram inoculados, de forma que a absorbância inicial fosse de 0,2 . O crescimento foi 
acompanhado através da medida da absorbância a $600 \mathrm{~nm}$ e, ao atingir o valor de 2,0, todo o conteúdo foi centrifugado, as células foram lavadas com solução salina $0,89 \%$ e foram ressuspendidas com meio $\mathrm{M} 9 \mathrm{com}$ adição de glicerol $10 \%$. O volume de meio com glicerol utilizado foi relativo à quantidade de células presente no frasco (estimado através da medida da absorbância), de forma a ter uma concentração de $10^{9}$ células $/ \mathrm{mL}$. O conteúdo foi distribuído em microtubos de $1,5 \mathrm{~mL}$ e congelados em freezer $-80^{\circ} \mathrm{C}$.

Para a construção do banco de trabalho, o processo foi repetido, no entanto partindo de um dos microtubos congelados do banco master. Um microtubo foi descongelado (retirado do freezer $-80^{\circ} \mathrm{C}$ e descongelado à temperatura ambiente) $\mathrm{e}$ $100 \mu \mathrm{L}$ foram utilizados para lançar um inóculo em $100 \mathrm{~mL}$ de meio mínimo definido M9. O processo descrito para a criação do banco master foi repetido e os tubos foram congelados a $-80^{\circ} \mathrm{C}$.

\subsection{Cultivos em frascos agitados}

Foram conduzidos experimentos com as linhagens SE1 e BL21(DE3) em frascos tipo Erlenmeyer de $500 \mathrm{~mL}$ em agitador orbital (Innova 44 - New Brunswick Scientific, Eppendorf Inc., Enfield, CT, EUA) a $37^{\circ} \mathrm{C}$ e agitação de $250 \mathrm{rpm}$.

\subsubsection{Cinética de crescimento}

A partir de um tubo do banco de trabalho, foram preparados inóculos em $100 \mathrm{~mL}$ de meio definido HDF, com $10 \mathrm{~g} / \mathrm{L}$ de glicose como fonte de carbono e $30 \mathrm{mg} / \mathrm{L}$ de sulfato de canamicina para a linhagem BL21(DE3). Após $16 \mathrm{~h}$, foram inoculados em novos $100 \mathrm{~mL}$ de meio HDF, de forma que a densidade óptica $(600 \mathrm{~nm})$ inicial fosse de 0 ,2. O ensaio foi conduzido em frascos tipo Erlenmeyer de $500 \mathrm{~mL}$ a $37^{\circ} \mathrm{C}$ e agitação de $250 \mathrm{rpm}$. Amostras foram coletadas a cada hora para acompanhamento da cinética de crescimento através da medida da absorbância com comprimento de onda a 600 $\mathrm{nm}$. 


\subsubsection{Ensaio de expressão}

Para o ensaio de expressão, inóculos em $100 \mathrm{~mL}$ de meio HDF com $10 \mathrm{~g} / \mathrm{L}$ de glicose como fonte de carbono foram preparados, e, para a linhagem BL21(DE3), 30 $\mathrm{mg} / \mathrm{L}$ de sulfato de canamicina foram adicionados. Após 16 horas, foram inoculados em novos $100 \mathrm{~mL}$ de meio HDF, com densidade óptica $(600 \mathrm{~nm})$ inicial de 0,2. No início da fase exponencial, foi feita a indução com IPTG (isopropil- $\beta$-D-tiogalactopiranosídeo) a 1 $\mathrm{mM}$, coletando amostras até a terceira hora após indução. Amostras após indução foram analisadas quanto à produção de proteína recombinante, utilizando método de Bradford (1976) para quantificação de proteína total, eletroforese em gel de poliacrilamida (SDS-PAGE) para determinação do perfil de massa das proteínas expressas e densitometria para determinação da quantidade de proteína recombinante produzida.

\subsubsection{Metodologia analítica}

As amostras coletadas do ensaio de expressão foram centrifugadas a $12.000 \mathrm{~g}$ por 5 minutos a $4{ }^{\circ} \mathrm{C}$ e o pellet resultante foi ressuspendido em tampão de lise (25 mM Tris- $\mathrm{HCl} \mathrm{pH}$ 7,5, $150 \mathrm{mM} \mathrm{NaCl}, 0,3 \mathrm{mg} / \mathrm{mL}$ lisozima, e $1 \mathrm{mM}$ PMSF), seguido de sonicação (Sonics - Vibra Cell, Sonics \& Materials Inc., Newtown, CT, EUA). As amostras foram novamente centrifugadas, sendo o sobrenadante recuperado para determinação de atividade enzimática e concentração de proteínas totais.

A concentração de proteínas totais foi determinada pelo método de Bradford (Bradford, 1976), utilizando o reagente Bio-Rad Protein Assay Dye Reagent (Bio-Rad Laboratories Inc., Hercules, CA, EUA), seguindo as instruções do fabricante. Para a curva de calibração, foi utilizada albumina de soro bovino (BSA), de 0,05-0,5 mg/mL. A expressão da proteína foi analisada qualitativamente através de eletroforese em gel de poliacrilamida (SDS-PAGE) 12\% (LAEMMLI, 1970), a $120 \mathrm{~V}$ por cerca de 1 horas 20 minutos. Após a corrida, os géis foram revelados com Azul Brilhante de Coomassie R250. As amostras foram ajustadas para aplicação correspondente à quantidade de $3 \mu \mathrm{g}$ de proteínas totais.

A atividade enzimática da $\beta-1,3-1,4-g l u c a n a s e$ foi determinada segundo protocolo de Ghose (1987), usando $\beta$-glucana $0,5 \%$ como substrato. $40 \mu \mathrm{L}$ de tampão 
acetato foram distribuídos em microplacas de 96 poços e $10 \mu \mathrm{L}$ da amostra foram adicionados, seguido de $50 \mu \mathrm{L}$ do substrato. Após a reação ser incubada a $50{ }^{\circ} \mathrm{C}$ por 30 minutos em termociclador (Eppendorf, EUA), a quantidade de açúcares redutores foi determinada pelo método do DNS (ácido 3,5-dinitro-salićlico) (MILLER, 1959). Após adicionar $100 \mu \mathrm{L}$ do reagente DNS, as placas foram incubadas a $99^{\circ} \mathrm{C}$ por 5 minutos em termociclador. A curva de calibração foi construída com concentrações de 0,5-5 mM de glicose. As placas foram levadas à leitora de microplacas Infinite M200 (TECAN, Suíça) para determinação da absorbância a $540 \mathrm{~nm}$. A unidade de atividade enzimática foi definida como sendo a quantidade de enzima que libera $1 \mathrm{mmol}$ de glicose por minuto, sendo que as atividades específicas foram determinadas como unidades internacionais por $\mathrm{mg}$ de proteína $(\mathrm{Ul} / \mathrm{mg})$.

\subsection{Cultivos em biorreator}

\subsubsection{Curva de calibração}

Para a determinação dos parâmetros cinéticos, foi realizado cultivo descontínuo com a linhagem SE1 em condições controladas em reator de 7,5 L, contendo $5 \mathrm{~L}$ de meio HDF, utilizando glicerol $20 \mathrm{~g} / \mathrm{L}$ como fonte de carbono. Os experimentos foram conduzidos em biorreatores Bioflo 115 (New Brunswick Scientific, EUA). A temperatura foi mantida a $30^{\circ} \mathrm{C}$ e o pH controlado em 7,0 através da adição de solução de $\mathrm{NH}_{4} \mathrm{OH}$ $25 \%(\mathrm{v} / \mathrm{v})$. O oxigênio dissolvido (OD) foi mantido em 30\% de saturação através do suprimento de ar de 1,0 a 6,0 VVM, agitação em cascata, entre 200 e 1000 rpm, e adição de oxigênio puro, caso necessário.

O cultivo foi iniciado com densidade óptica $(600 \mathrm{~nm})$ de 0,2 e as amostras foram coletadas a cada 2 horas. As amostras coletadas tiveram a densidade óptica (600nm) registrada e foram centrifugadas, sendo o centrifugado lavado duas vezes com solução salina $0,89 \%$ antes de ser conduzido à estufa a $80^{\circ} \mathrm{C}$ para secagem e determinação da massa seca. Com os valores de densidade óptica e massa seca, foi plotado o gráfico para determinar a correlação linear dos parâmetros citados. 


\subsubsection{Determinação de parâmetros cinéticos}

Foram conduzidos experimentos com condições controladas em cultivo descontínuo para a obtenção dos parâmetros cinéticos da linhagem SE1. O microrganismo foi cultivado em $1 \mathrm{~L}$ de meio HDF, utilizando como fonte de carbono glicerol a $10 \mathrm{~g} / \mathrm{L}$. Os experimentos foram conduzidos em biorreatores de $3 \mathrm{~L}$ Bioflo 115 (New Brunswick Scientific, EUA). A temperatura foi mantida a $37^{\circ} \mathrm{C}$ e o pH controlado em 7,0 através da adição de solução de $\mathrm{NH}_{4} \mathrm{OH} 25 \%$ (v/v). O oxigênio dissolvido (OD) foi mantido em $30 \%$ de saturação através do suprimento de ar a 1,0 VVM e agitação em cascata, entre 200 e 1000 rpm. O cultivo iniciou com a absorbância (60 0nm) inicial de 0,2 e amostras foram coletadas a cada hora.

As amostras coletadas foram centrifugadas, sendo o sobrenadante enviado para análise por HPLC (High Performance Liquid Chromatography - cromatografia líquida de alta performance) acoplado a detectores de UV e índice de refração. As amostras foram diluídas e injetadas na coluna HPX-87H (BioRad) a $50{ }^{\circ} \mathrm{C}$, com ácido sulfúrico 0,005 M a 0,5 mL/min como fase móvel para a análise de açúcares e ácidos orgânicos.

Os dados experimentais dos cultivos descontínuos foram utilizados para estimar a velocidade específica de crescimento $\left(\mu_{x}\right)$ (Equação 2 ), fator de conversão em biomassa (Yx/s) (Equação 3), produtividade em biomassa (Px) (Equação 4), e velocidade específica de consumo de substrato $\left(\mu_{\mathrm{s}}\right)$ (Equação 5$)$.

$$
\mu_{X}=\frac{1}{X} \frac{d X}{d t}
$$

$\mu_{\mathrm{x}}$ : velocidade específica de crescimento $\left(\mathrm{h}^{-1}\right)$

$\mathrm{X}$ : concentração de células $\left(\mathrm{g} \cdot \mathrm{L}^{-1}\right)$

$$
Y_{X / S}=\frac{X-X_{0}}{S_{0}-S}
$$

Yx/s: Fator de conversão de substrato em biomassa ( $g_{\text {céls. }} g^{-1}$ substrato)

$\mathrm{X}$ : concentração de células $\left(\mathrm{g} \cdot \mathrm{L}^{-1}\right)$

S: concentração de substrato $\left(\mathrm{g} \cdot \mathrm{L}^{-1}\right)$ 


$$
P_{X}=\frac{X-X_{0}}{t}
$$

Px: produtividade em biomassa $\left(\mathrm{g} \cdot \mathrm{L}^{-1} \cdot \mathrm{h}^{-1}\right)$

$\mathrm{X}$ : concentração de células $\left(\mathrm{g} \cdot \mathrm{L}^{-1}\right)$

t: tempo total do cultivo $(h)$

$$
\mu_{s}=-\frac{1}{X} \frac{d S}{d t}
$$

$\mu_{\mathrm{s}}$ : velocidade específica de consumo de substrato $\left(\mathrm{g}_{\text {substrato. }} \cdot \mathrm{gcé}^{-1} \mathrm{~s}^{-1} \cdot \mathrm{h}^{-1}\right)$

S: concentração de substrato $\left(\mathrm{g} \cdot \mathrm{L}^{-1}\right)$

$\mathrm{X}$ : concentração de células $\left(\mathrm{g} \cdot \mathrm{L}^{-1}\right)$

\subsection{Estabilidade plasmidial}

\subsubsection{Avaliação da estabilidade plasmidial pela resistência ao antibiótico}

Foram conduzidos cultivos em condições controladas para verificar a estabilidade plasmidial nas linhagens BL21 e SE1. Os microrganismos foram cultivados em $150 \mathrm{~mL}$ de meio HDF, utilizando como fonte de carbono glicerol $10 \mathrm{~g} / \mathrm{L}$. Os experimentos foram conduzidos em mini biorreatores de $250 \mathrm{~mL}$ DASGIP (DASbox Mini Bioreactor - Eppendorf, EUA). A temperatura foi mantida a $30{ }^{\circ} \mathrm{C}$ e $\circ \mathrm{pH}$ controlado em 7,0 através da adição de solução de $\mathrm{NH}_{4} \mathrm{OH} 25 \%$ (v/v). O oxigênio dissolvido (OD) foi mantido em $30 \%$ de saturação através do suprimento de ar a 1,0 VVM e agitação em cascata, entre 250 e 1200 rpm. Os clones com a linhagem BL21(DE3) foram testados quanto à estabilidade em cultivo na presença e na ausência do antibiótico (sulfato de canamicina $30 \mu \mathrm{g} / \mathrm{mL}$ ). Foram lançados inóculos em meio HDF com $10 \mathrm{~g} / \mathrm{L}$ de glicerol a $37{ }^{\circ} \mathrm{C}$ e $250 \mathrm{rpm}$ por 16 horas. Os reatores foram inoculados e o cultivo foi iniciado com a absorbância $(600 \mathrm{~nm})$ de 0,2.

A partir da indução com IPTG 1 mM (densidade óptica próxima de 5,0), foram coletadas amostras até a terceira hora e plaqueadas em meio LB solidificado. Tais 
placas foram mantidas em estufa a $37{ }^{\circ} \mathrm{C}$. Após 16 horas, colônias isoladas foram repicadas (100 colônias isoladas ou o maior número possível) em placas com LB solidificado com antibiótico (sulfato de canamicina $30 \mu \mathrm{g} / \mathrm{mL}$ ) e novamente incubadas a $37^{\circ} \mathrm{C}$ por pelo menos 16 horas. A estabilidade dos plasmídeos foi determinada através da percentagem de colônias que cresceram na placa com o antibiótico em relação ao número total de colônias que foram repicadas a partir da placa sem o antibiótico.

\subsubsection{Número de Cópias de Plasmídeos}

Foi realizado um experimento para a verificação do comportamento das células quanto ao número de cópias de plasmídeos em resposta à indução, seguindo procedimento experimental descrito por Carapuça e colaboradores (2007). Para isso, foram realizados cultivos em mini biorreatores de $250 \mathrm{~mL}$ DASGIP (DASbox Mini Bioreactor - Eppendorf). A temperatura foi mantida a $30^{\circ} \mathrm{C}$ e o pH controlado em 7,0 através da adição de solução de $\mathrm{NH}_{4} \mathrm{OH} 25 \%$ (v/v). O oxigênio dissolvido (OD) foi mantido em $30 \%$ de saturação através do suprimento de ar a 1,0 VVM e agitação em cascata, entre 250 e 1200 rpm. Foram preparados inóculos dos clones de expressão de endoglucanase nas linhagens SE1 e BL21(DE3) em frascos agitados, em meio HDF com glicerol $10 \mathrm{~g} / \mathrm{L}$ como fonte de carbono, incubados a $37^{\circ} \mathrm{C}$ por 16 horas. Após este período, os reatores foram inoculados para início do cultivo em DO 0,2. Quando os cultivos apresentaram o valor próximo de 2,0 de DO, foram induzidos com IPTG 1mM. A partir do momento da indução foram coletadas amostras a cada hora (até a terceira hora) e imediatamente congeladas para subsequente análise em real-time $P C R$ (qPCR).

Para determinação do número de plasmídeo por qPCR, é necessário realizar uma curva de calibração. Assim, foi realizada uma curva ( 0 pg, 1 pg, 10 pg, 100 pg, 1 ng e $10 \mathrm{ng}$ ) com os plasmídeos end_ccdA/pET28a e end/pET28a, previamente extraídos e purificados, quantificados através do espectrofotômetro NanoDrop 2000c (Thermo Scientific, EUA). Para determinação quantitativa dos plasmídeos presentes na curva e na amostra, foram utilizados os oligonucleotídeos endF' e endR' (Tabela 3). 
Tabela 3 - Oligonucleotídeos utilizados na qPCR

\begin{tabular}{ll}
\hline Oligonucleotídeo & Sequência \\
\hline endF' & 5' - GAGCCAGGATGTGAATGATG - 3' \\
endR' & 5' - GCTCCTTTGCTGAGTGCATA - 3' \\
\hline
\end{tabular}

As amostras coletadas foram diluídas de forma a terem a quantidade de 2,5 $\mathrm{x}$ $10^{5}$ células por reação de qPCR. Para a curva de calibração, foi realizado spiking de células BL21(DE3) vazias (sem a presença de plasmídeos) na mesma quantidade de células.

O volume final da reação foi de $10 \mu \mathrm{L}$, em microtubos de $0,1 \mathrm{~mL}$ de acordo com as quantidades apresentadas abaixo:

- $5 \mu \mathrm{L}$ SYBR Green Master Mix (Qiagen, California, EUA)

- 0,2 $\mu \mathrm{L}$ de cada oligonucleotídeo a $20 \mathrm{pmol} / \mu \mathrm{L}$

- $4 \mu \mathrm{L}$ de amostra

- $\mathrm{H}_{2} \mathrm{O}$ q.s.p. $10 \mu \mathrm{L}$

Após distribuídas as reações em cada microtubo, eles foram levados ao termociclador Rotor-Gene Q (Qiagen, EUA), e foram submetidos à ciclagem:

- $95^{\circ} \mathrm{C} 10$ minutos

- 45 ciclos: $95^{\circ} \mathrm{C}$ por 15 segundos $+60^{\circ} \mathrm{C}$ por 1 minuto $+60^{\circ} \mathrm{C}$ por 1 minuto

- $60{ }^{\circ} \mathrm{C}$ a $95^{\circ} \mathrm{C}$ para curva de melting $\left(1^{\circ} \mathrm{C} /\right.$ minuto $)$

Os resultados foram capturados em tempo real e analisados através do software acoplado ao termociclador para quantificação do número de plasmídeos. 


\subsection{Determinação da concentração do indutor}

\subsubsection{Ensaio em microtubos}

Foram realizados estudos para a determinação da concentração mínima do indutor IPTG (isopropil- $\beta$-D-tiogalactopiranosídeo) necessária para a expressão das proteínas. A partir do banco de trabalho da linhagem SE1 contendo o plasmídeo end_ccdA/pET28a, foi lançado um inóculo a $37^{\circ} \mathrm{C}, 250 \mathrm{rpm}$ em $100 \mathrm{~mL}$ de meio HDF suplementado com $10 \mathrm{~g} / \mathrm{L}$ glicose. Ao atingir 1,6 de absorbância $(600 \mathrm{~nm})$, foram distribuídos $1,1 \mathrm{~mL}$ em microtubos de $2 \mathrm{~mL}$, cada um contendo $0,1 \mathrm{~mL}$ de solução de IPTG para as concentrações finais de: $0 \mathrm{mM}, 0,01 \mathrm{mM}, 0,05 \mathrm{mM}, 0,1 \mathrm{mM}, 0,3 \mathrm{mM}, 0,5$ $\mathrm{mM}$ e $1 \mathrm{mM}$. Após 3 horas de indução, o volume total das amostras foi coletado.

Amostras antes da indução foram coletadas para a determinação da massa seca no momento da adição do IPTG. Nas amostras após indução foram determinados: a concentração da proteína total pelo método de Bradford (1976), o perfil de massa das proteínas presentes na amostra através de eletroforese em gel de poliacrilamida (SDSPAGE) $12 \%$ e a concentração de proteína recombinante produzida através de densitometria de banda utilizando uma curva de calibração com concentrações conhecidas de albumina de soro bovino.

\subsubsection{Ensaio em reatores}

Foram conduzidos experimentos com condições controladas em cultivo descontínuo para a determinação da concentração mínima de IPTG necessária para a expressão das proteínas na linhagem SE1. Os microrganismos foram cultivados em $150 \mathrm{~mL}$ de meio HDF, utilizando como fonte de carbono glicerol $10 \mathrm{~g} / \mathrm{L}$. Os experimentos foram conduzidos em mini biorreatores de $250 \mathrm{~mL}$ DASGIP (DASbox Mini Bioreactor - Eppendorf, EUA). A temperatura foi mantida a $30{ }^{\circ} \mathrm{C} \mathrm{e} \mathrm{o} \mathrm{pH}$ controlado em 7,0 através da adição de solução de $\mathrm{NH}_{4} \mathrm{OH} 25 \%$ (v/v). O oxigênio dissolvido (OD) foi mantido em $30 \%$ de saturação através do suprimento de ar a 1,0 VVM e agitação em cascata, entre 250 e 1200 rpm.

A partir do banco de trabalho da linhagem SE1 contendo o plasmídeo end_ccdA/pET28a, foi lançado um inóculo a $37{ }^{\circ} \mathrm{C}, 250 \mathrm{rpm}$ em $100 \mathrm{~mL}$ de meio HDF 
suplementado com $10 \mathrm{~g} / \mathrm{L}$ glicose. Ao atingir o valor em torno de 2,0 de absorbância $(600 \mathrm{~nm})$, foram inoculados os reatores de forma que os cultivos iniciassem com absorbância de 0,2. Ao atingir a densidade óptica em torno de 5,0, os cultivos foram induzidos com solução de IPTG. As concentrações finais testadas foram: $0 \mathrm{mM}, 0,025$ $\mathrm{mM}, 0,05 \mathrm{mM}, 0,1 \mathrm{mM}, 0,25 \mathrm{mM}, 0,5 \mathrm{mM}$ e $1 \mathrm{mM}$. Após 3 horas de indução, foram coletadas amostras para determinação da massa seca (através da densidade óptica medida), proteína total pelo método de Bradford (1976), perfil de massa das proteínas presentes na amostra através de eletroforese em gel de poliacrilamida (SDS-PAGE) $12 \%$ e concentração de proteína recombinante produzida através de densitometria de banda. 


\section{RESULTADOS}

\subsection{Obtenção dos sistemas de expressão}

O gene ccdA foi extraído do vetor de clonagem pStaby, obtido a partir do kit da Delphi Genetics, e clonado nos plasmídeos end/pET28a e exp/pET28a. Para verificar a presença dos genes da endoglucanase, expansina e ccdA, foram realizadas reações de PCR utilizando oligonucleotídeos específicos para cada gene (Tabela 2).

As imagens do gel de agarose evidenciaram que os resultados das reações de PCR confirmaram a presença dos insertos nos plasmídeos, indicando amplicons no tamanho esperado (484 bp para o ccdA, 1432 bp para a endoglucanase e 624 bp para a expansina) (Figura 4).

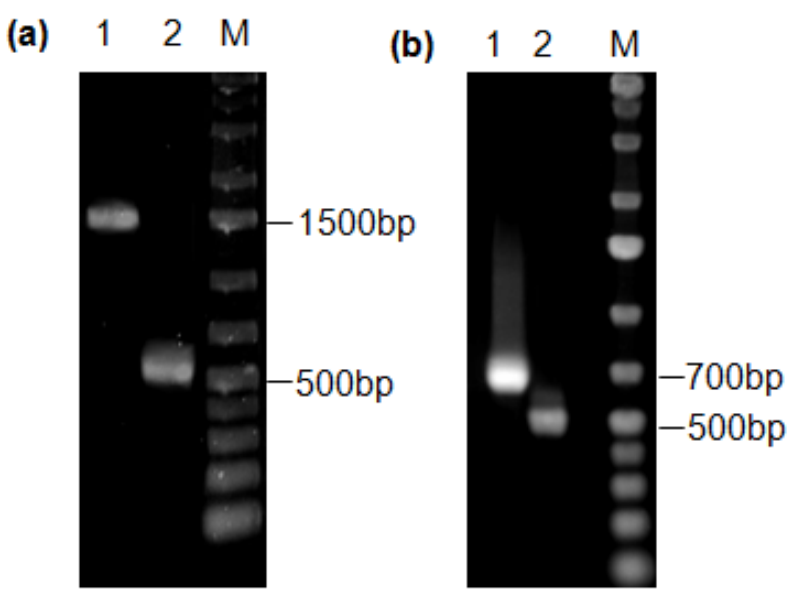

Figura 4 - Gel de agarose $1 \%$ com produtos de PCR para confirmação da clonagem. 4a) Confirmação da presença do inserto de endoglucanase (1) e ccdA (2). 4b) Confirmação da presença do inserto de expansina (1) e ccdA (2). M: GeneRuler $1 \mathrm{~kb}$ Plus DNA Ladder (Thermo Scientific).

\subsection{Ensaios em frascos agitados}

As linhagens SE1 e BL21(DE3) transformadas com plasmídeos contendo o inserto para a expressão de expansina e endoglucanase foram avaliadas quanto ao seu perfil cinético em ensaios em frascos agitados conforme descrito em Material e Métodos. A partir dos valores de absorbância das amostras coletadas, foi possível 
traçar um gráfico para comparar o perfil de crescimento das linhagens SE1 e BL21(DE3) (Figura 5). Os valores máximos de absorbância apresentados foram de 6,2 $\pm 0,1$ para endoglucanase e 6,4 $\pm 0,0$ para expansina na linhagem SE1 e 4,2 $\pm 0,0$ (endoglucanase) e 4,2 $\pm 0,1$ (expansina) na linhagem BL21(DE3).
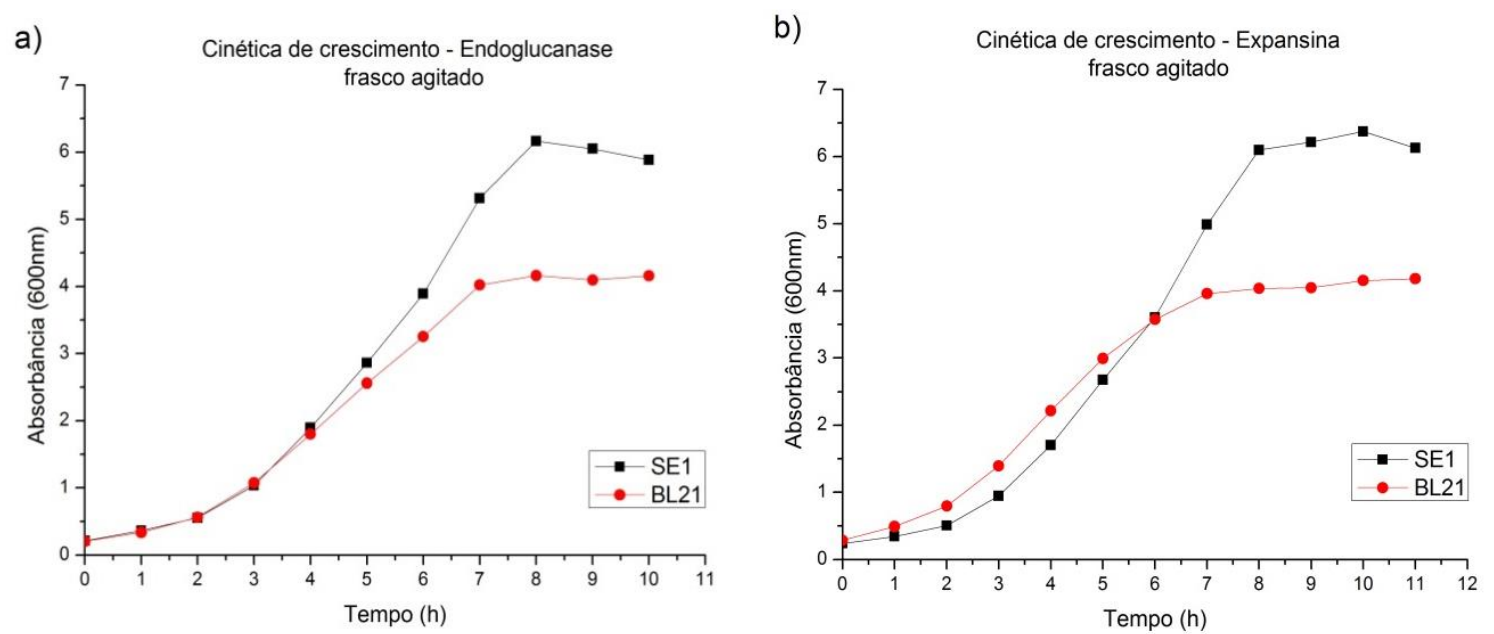

Figura 5 - Perfil cinético de crescimento a partir dos valores de absorbância nos ensaios de cultivo em frasco agitado. 5a) Cinética de crescimento das linhagens SE1 e BL21(DE3) contendo gene da endoglucanase. 5b) cinética de crescimento das linhagens SE1 e BL21(DE3) contendo o gene da expansina.

Nos ensaios de expressão, amostras a cada hora foram coletadas para o acompanhamento da densidade óptica a $600 \mathrm{~nm}$ (Figura 6) e a indução ocorreu em absorbância em torno de 1,8. Ao final do cultivo, as amostras coletadas foram aplicadas em SDS-PAGE (Figura 7) e dosadas com relação à quantidade de proteína total e proteína recombinante (Tabela 4), comparando-se o desempenho de cada linhagem em condições de cultivo e expressão em frascos agitados. 

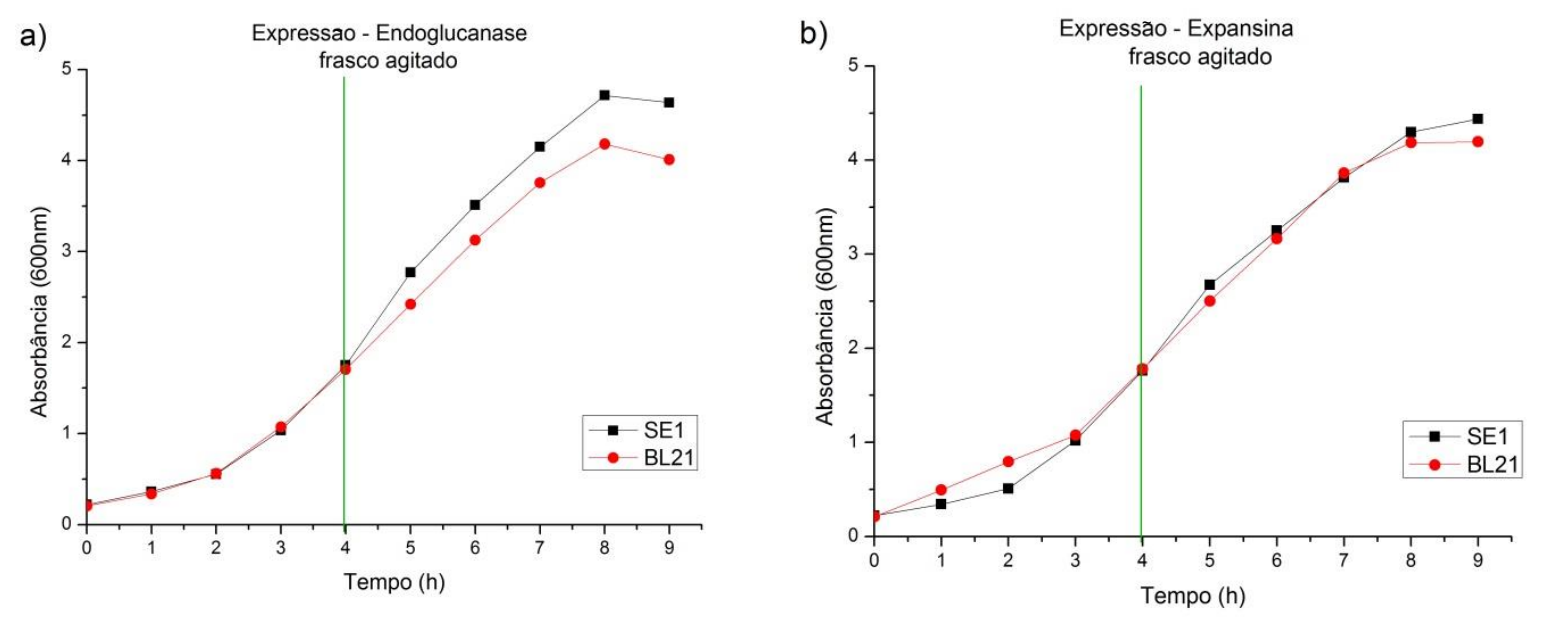

Figura 6 - Perfil cinético de crescimento comparando as linhagens SE1 e BL21(DE3) a partir dos valores de absorbância nos ensaios de cultivo e expressão em frasco agitado. 6a) Cinética de crescimento das linhagens SE1 e BL21(DE3) contendo gene da endoglucanase. 6b) cinética de crescimento das linhagens SE1 e BL21(DE3) contendo o gene da expansina. A linha verde vertical indica o momento da indução.

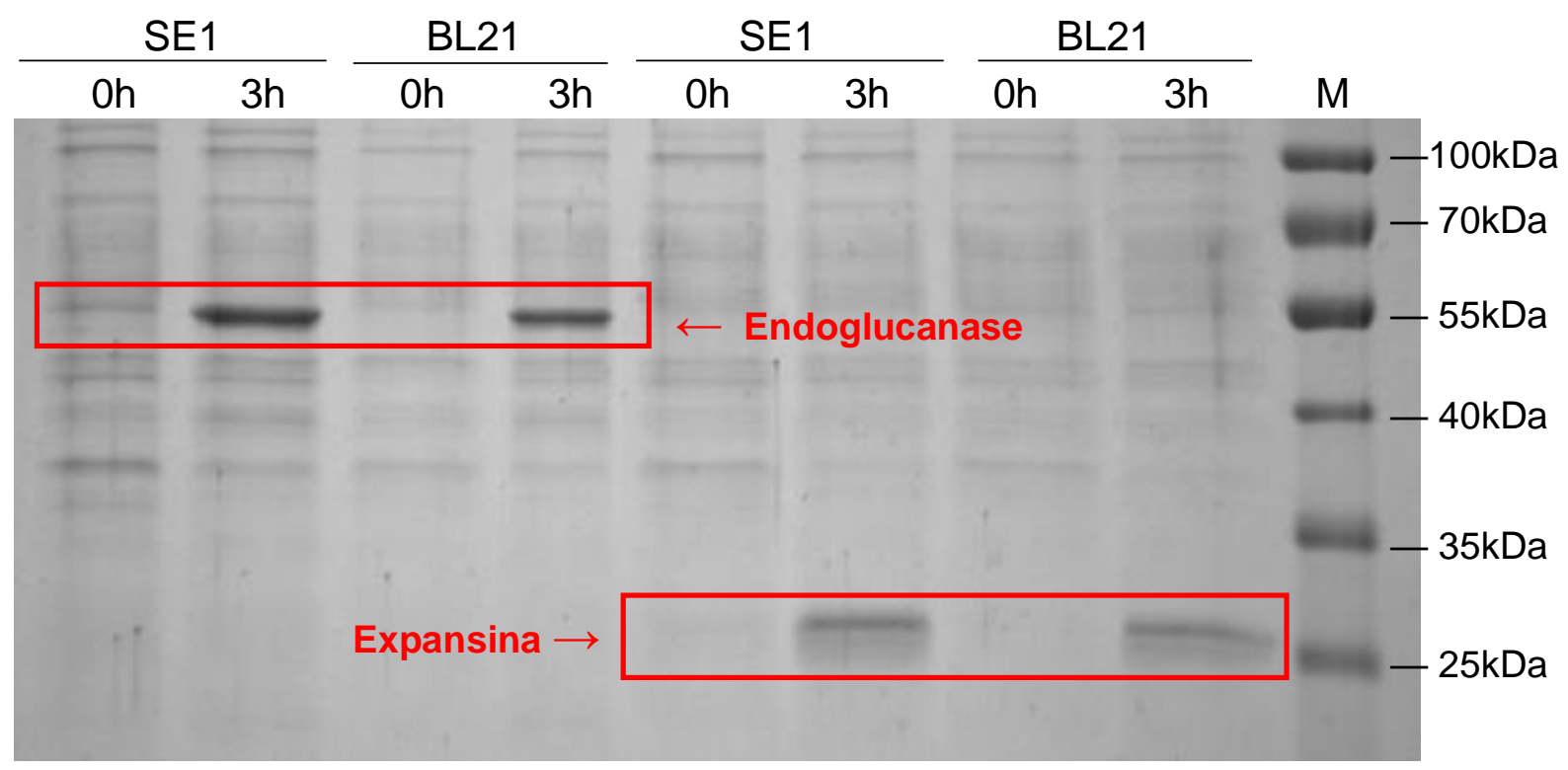

Figura 7 - Gel de SDS-PAGE com amostras antes e após 3 horas de indução das proteínas endoglucanase e expansina nas linhagens SE1 e BL21. M: marcador de peso molecular (PageRuler Prestained Protein Ladder - ThermoScientific). 
Tabela 4 - Parâmetros obtidos ao final do cultivo nos ensaios de expressão em frasco agitado.

\begin{tabular}{ccccc}
\hline Parâmetro & $\begin{array}{c}\text { Endoglucanase } \\
\text { BL21(DE3) }\end{array}$ & $\begin{array}{c}\text { Endoglucanase } \\
\text { SE1 }\end{array}$ & $\begin{array}{c}\text { Expansina } \\
\text { BL21(DE3) }\end{array}$ & $\begin{array}{c}\text { Expansina } \\
\text { SE1 }\end{array}$ \\
\hline $\begin{array}{c}\text { Densidade óptica } \\
(\mathbf{6 0 0} \mathbf{~ n m ) ~}\end{array}$ & $4,0 \pm 0,0$ & $4,6 \pm 0,0$ & $4,2 \pm 0,0$ & $4,4 \pm 0,0$ \\
\hline $\begin{array}{c}\text { Proteína total (g/L) } \\
\text { Proteína }\end{array}$ & $0,4 \pm 0,0$ & $0,4 \pm 0,0$ & $0,3 \pm 0,0$ & $0,4 \pm 0,0$ \\
$\begin{array}{c}\text { recombinante (\%) } \\
\begin{array}{c}\text { Proteína } \\
\text { recombinante (mg/L) }\end{array}\end{array}$ & $12,1 \pm 1,3$ & $17,0 \pm 2,2$ & $9,5 \pm 1,0$ & $12,0 \pm 0,5$ \\
\hline
\end{tabular}

\subsection{Ensaios em biorreator}

\subsubsection{Curva de calibração}

Para a determinação dos parâmetros cinéticos dependentes da concentração de biomassa, foi realizada a curva de calibração para correlação da massa seca ( $g / L)$ e densidade óptica a $600 \mathrm{~nm}$ para os ensaios posteriores.

Sendo assim, durante o cultivo do clone da linhagem SE1 contendo plasmídeo end_ccdA/pEt28a, as amostras coletadas a cada duas horas foram processas para a obtenção da absorbância (600 nm) (Figura 8a) e massa seca (Figura 8b). Com estes dados, foi possível plotar o gráfico de massa seca x absorbância, obtendo-se então a equação para determinação da biomassa referente à absorbância medida (Figura 9). 


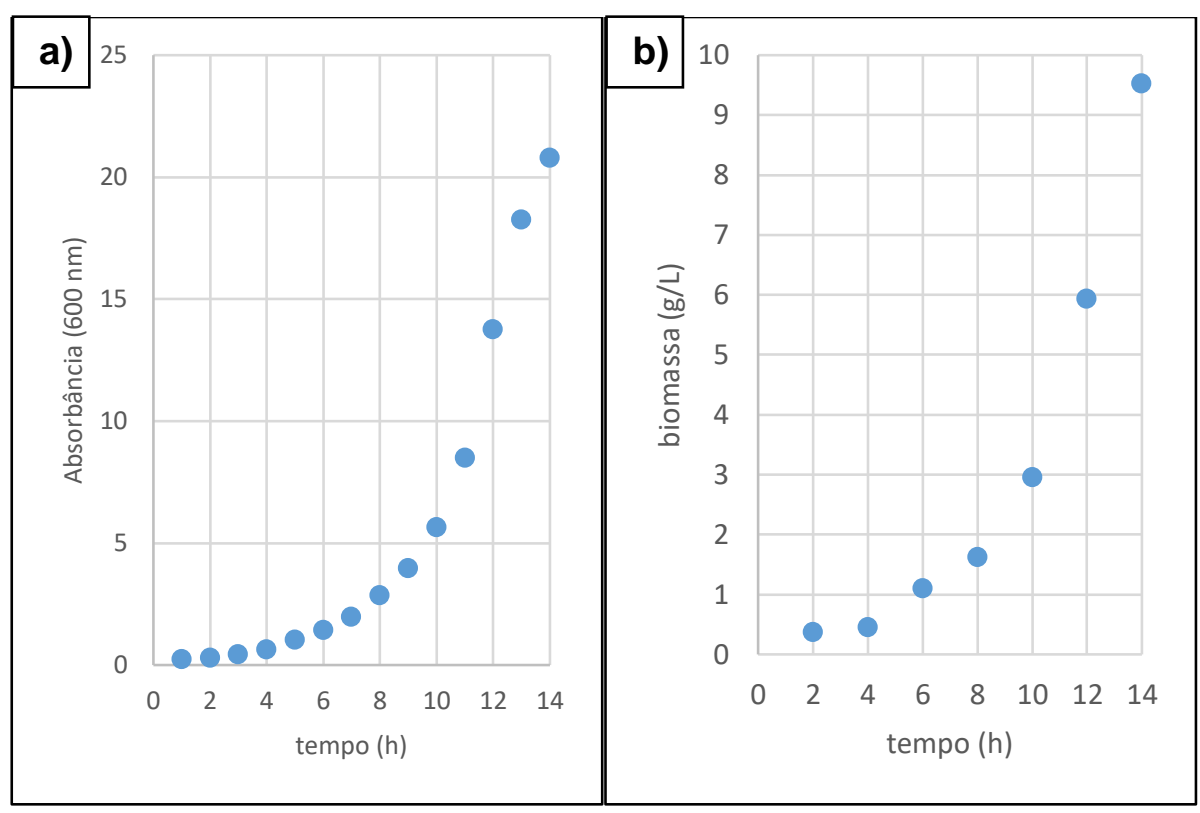

Figura 8 - Dados obtidos para curva de calibração para correlação de massa seca e absorbância. 8a) Valores de absorbância por tempo obtidos durante o cultivo. 8b) Valores de massa seca por tempo obtidos durante o cultivo.

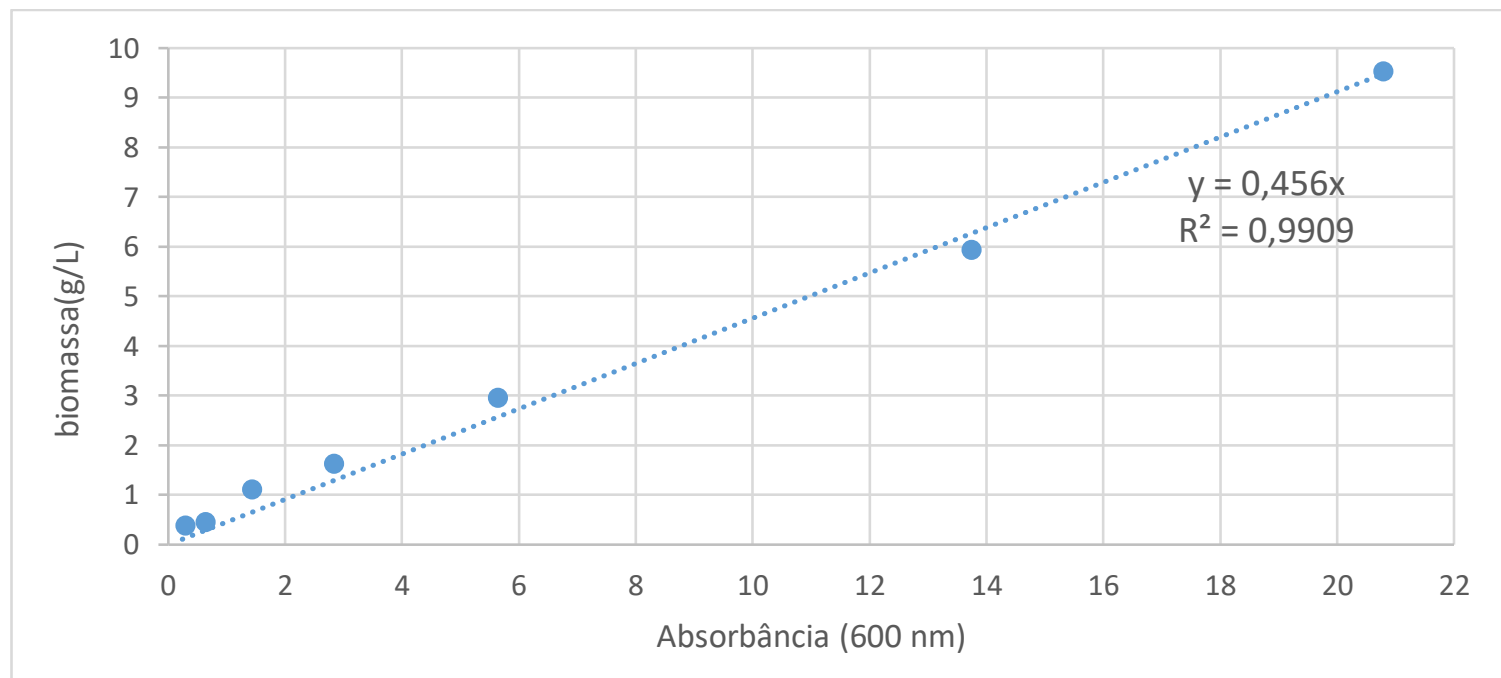

Figura 9 - Curva de calibração obtida para correlação de absorbância a 600nm e biomassa seca $(\mathrm{g} / \mathrm{L})$

\subsubsection{Parâmetros cinéticos}

Foram conduzidos ensaios em biorreator de $3 \mathrm{~L}$ para obtenção da cinética de crescimento dos clones em linhagem SE1. Parâmetros como velocidade específica de 
crescimento, fator de conversão de substrato em célula, produtividade em biomassa e consumo de substrato são importantes para o planejamento de ensaios de expressão e cultivos alimentados. A partir das amostras coletadas, foram obtidos os perfis de crescimento (Figura 10) e consumo de substrato (glicerol) (Figura 11). Com os dados de produção de biomassa e consumo de substrato, foram calculados: a velocidade específica de crescimento $\mu_{x}$ (Figura 12), fator de conversão de substrato em célula (Figura 13) e velocidade específica de consumo de substrato $\mu_{\mathrm{s}}$ para cada clone. Os valores obtidos para os parâmetros estão apresentados na Tabela 5.

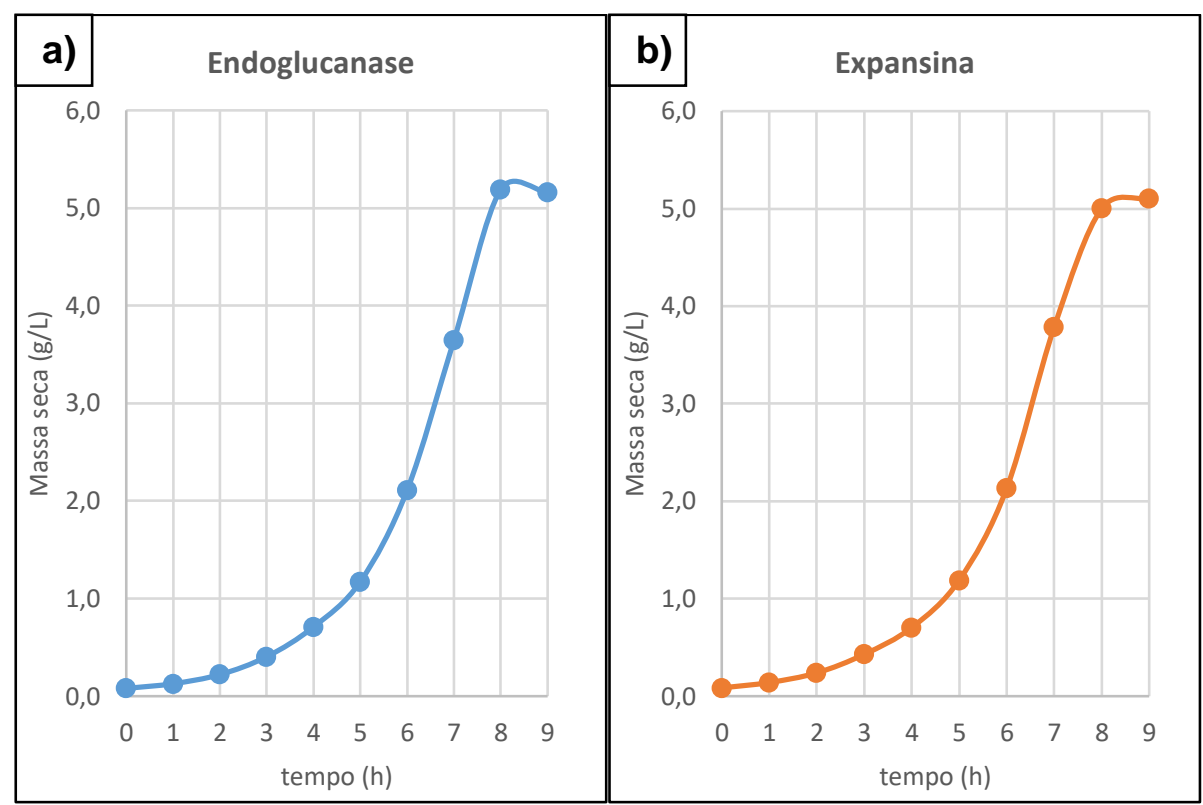

Figura 10 - Perfil cinético de crescimento em cultivo em reator de $3 \mathrm{~L}$ a partir dos valores de massa seca dos clones de expressão de endoglucanase (10a) e expansina (10b) em linhagem SE1. 


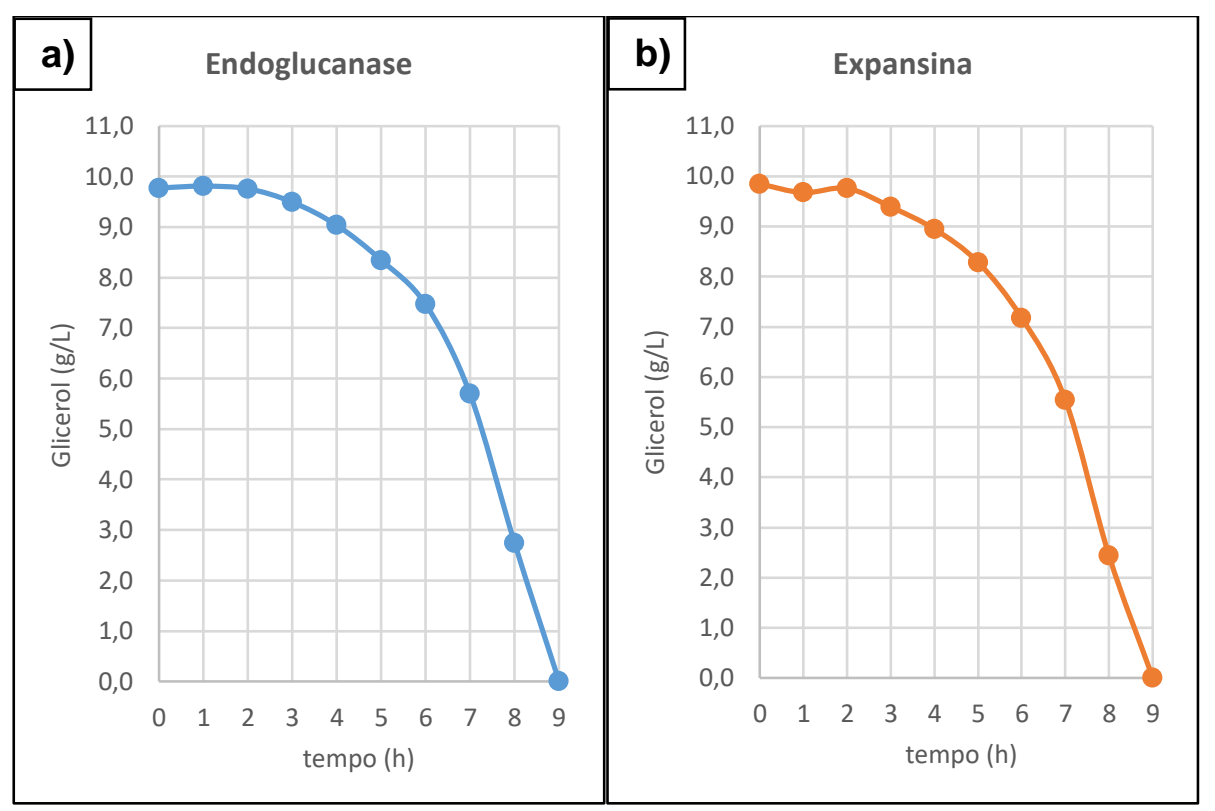

Figura 11 - Perfil de consumo de substrato em cultivo em reator de $3 \mathrm{~L}$ dos clones de expressão de endoglucanase (11a) e expansina (11b) em linhagem SE1.

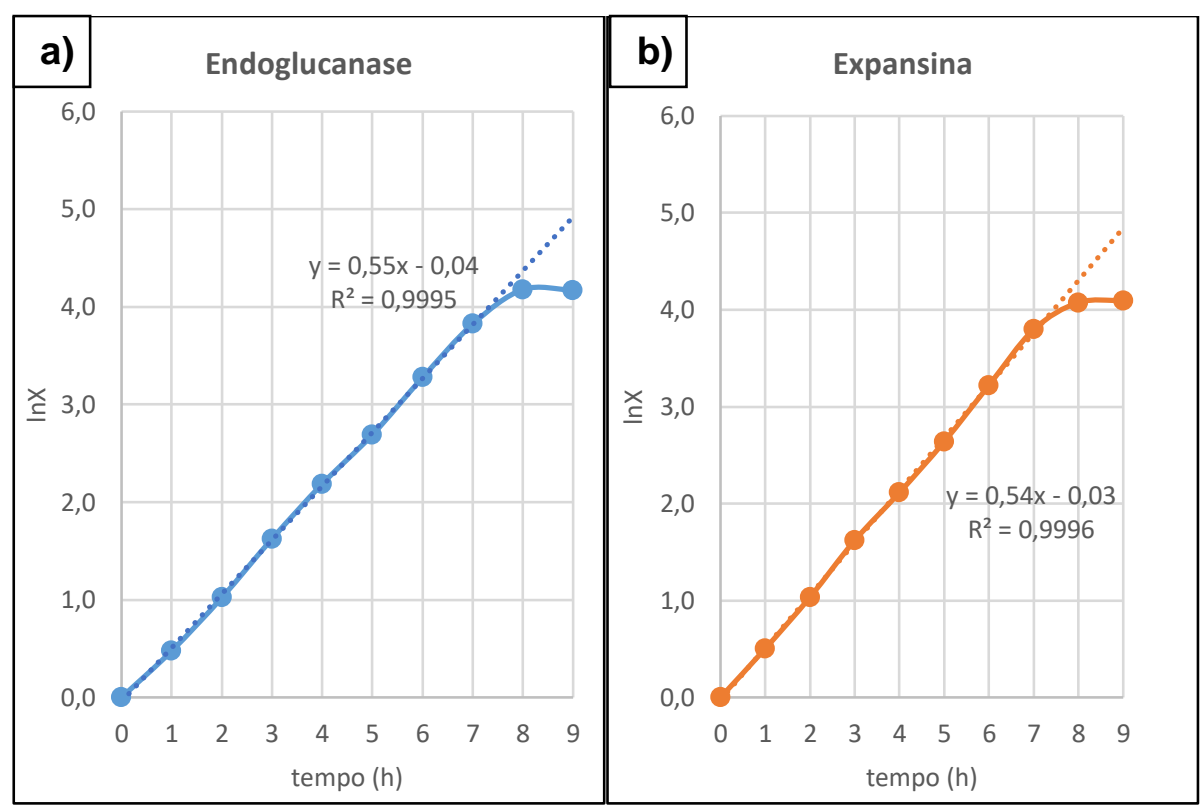

Figura 12 - Gráficos para a obtenção da velocidade específica de crescimento $\mu_{x}$ para ambos os clones em linhagem SE1. Foram plotados os valores dos logaritmos neperianos dos valores de massa seca em relação ao tempo inicial para os clones de SE1 expressando endoglucanase (12a) e expansina (12b). O valor de $\mu_{x}$ é dado pelo coeficiente angular obtido do ajuste da equação de primeira ordem aos dados da curva. 


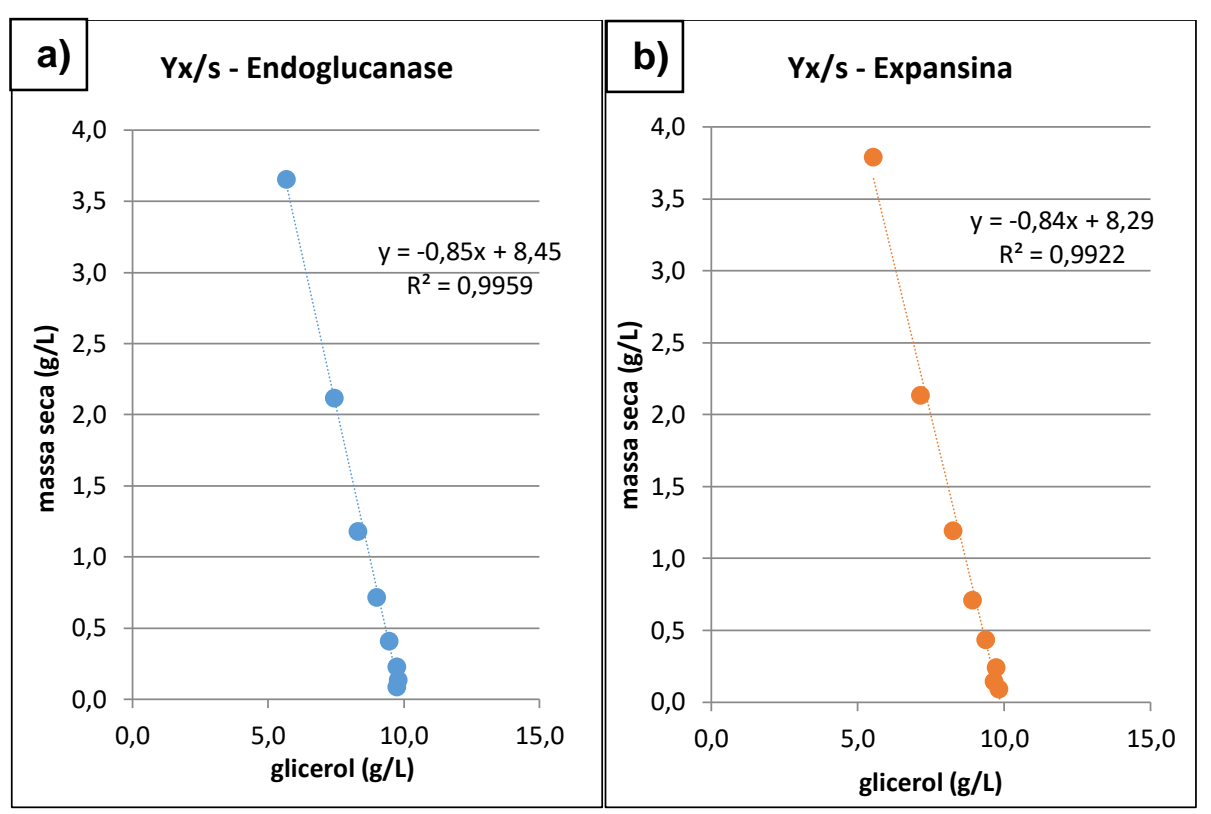

Figura 13 - Gráficos para a obtenção do fator de conversão de substrato em célula (YX/s) para ambos os clones em linhagem SE1. Foram plotados os valores de massa seca obtidos em relação ao glicerol presente no determinado tempo para os clones expressando endoglucanase (13a) e expansina (13b). O valor de $\mathrm{Yx} / \mathrm{s}$ é dado pelo coeficiente angular obtido, expresso em gramas de células por gramas de glicerol.

Tabela 5 - Parâmetros cinéticos obtidos a partir de cultivo em reator de $3 \mathrm{~L}$.

\begin{tabular}{lll}
\hline Parâmetro & Endoglucanase & Expansina \\
\hline $\boldsymbol{\mu}_{\mathbf{x}}\left(\mathbf{h}^{-1}\right)$ & 0,55 & 0,54 \\
$\boldsymbol{\mu}_{\mathbf{s}}\left(\mathbf{g}_{\text {glicerol }} \cdot \mathbf{g}_{\text {células }}{ }^{-1} \cdot \mathbf{h}^{-1}\right)$ & 0,63 & 0,63 \\
$\mathbf{Y}_{\mathbf{x} / \mathbf{s}}\left(\mathbf{g}_{\text {células }} \cdot \mathbf{g}^{-1}\right.$ glicerol $)$ & 0,85 & 0,84 \\
$\left.\mathbf{P x}_{\mathbf{x}} \mathbf{g}_{\text {células. }} \mathbf{L}^{-1} \cdot \mathbf{h}^{-1}\right)$ & 0,64 & 0,61 \\
Biomassa $\left(\mathbf{g} \cdot \mathbf{L}^{-1}\right)$ & 5,19 & 5,11 \\
Densidade óptica $(\mathbf{6 0 0} \mathbf{n m})$ & 11,38 & 11,2 \\
\hline
\end{tabular}

\section{$5.4 \quad$ Estabilidade plasmidial}

\subsubsection{Avaliação da estabilidade pela resistência ao antibiótico}

No estudo da estabilidade do plasmídeo durante o cultivo após a indução, foram coletadas amostras por 3 horas após a adição do indutor (IPTG 1 mM). As amostras 
foram plaqueadas em meio LB solidificado (não seletivo). Em seguida, colônias isoladas foram repicadas em meio LB solidificado seletivo, contendo o antibiótico canamicina ( $30 \mu \mathrm{g} / \mathrm{mL}$ ). Foi considerado que somente as colônias que cresceram em meio seletivo é que continham o plasmídeo, o qual contém o gene de resistência para o antibiótico citado.

As colônias que cresceram em meio com antibiótico foram contabilizadas e foi calculado o percentual destas colônias com relação ao número de total repicadas, obtendo, portanto, o número de células que mantinham o plasmídeo.

Para a linhagem BL21(DE3) foram realizados cultivos na presença e ausência do antibiótico, para os clones de endoglucanase e expansina (Tabela 6). Para a linhagem SE1, foi realizado o cultivo somente na ausência de antibiótico, para ambos clones (Tabela 7).

Tabela 6 - Estabilidade plasmidial durante a fase de indução para cultivos com e sem a presença de antibiótico, utilizando a linhagem BL21(DE3) para expressão das proteínas endoglucanase e expansina.

\begin{tabular}{ccccc}
\hline \multirow{2}{*}{$\begin{array}{c}\text { Tempo a partir } \\
\text { da indução }(\mathrm{h})\end{array}$} & \multicolumn{2}{c}{ Endoglucanase } & \multicolumn{2}{c}{ Expansina } \\
\cline { 2 - 5 } & Sem antibiótico & Com antibiótico & Sem antibiótico & Com antibiótico \\
\hline 0 & $98 \%$ & $97 \%$ & $92 \%$ & $96 \%$ \\
1 & $88 \%$ & $93 \%$ & $78 \%$ & $95 \%$ \\
2 & $92 \%$ & $92 \%$ & $72 \%$ & $85 \%$ \\
3 & $66 \%$ & $90 \%$ & $66 \%$ & $91 \%$ \\
\hline
\end{tabular}

Tabela 7 - Estabilidade plasmidial durante a fase de indução para cultivos utilizando a linhagem SE1, sem a presença de antibiótico, para expressão das proteínas endoglucanase e expansina.

\begin{tabular}{ccc}
\hline $\begin{array}{c}\text { Tempo a partir da } \\
\text { indução (h) }\end{array}$ & Endoglucanase & Expansina \\
\hline 0 & $100 \%$ & $100 \%$ \\
1 & $100 \%$ & $100 \%$ \\
2 & $100 \%$ & $100 \%$ \\
3 & $100 \%$ & $100 \%$ \\
\hline
\end{tabular}




\subsubsection{Número de Cópias de Plasmídeos}

Após verificar uma queda considerável na velocidade de crescimento ao induzir a expressão das proteínas nos cultivos com a linhagem SE1 quando comparada ao cultivo sem indução, foi realizado um estudo para verificar se havia uma correlação entre o comportamento do número de cópias de plasmídeos e esta queda na velocidade de crescimento. Através dos experimentos da quantificação do número de cópias ao longo do cultivo, foram gerados os gráficos (Figura 14) do perfil da concentração de plasmídeos (em nanogramas/ $\mu \mathrm{L}$ ) para cada linhagem.
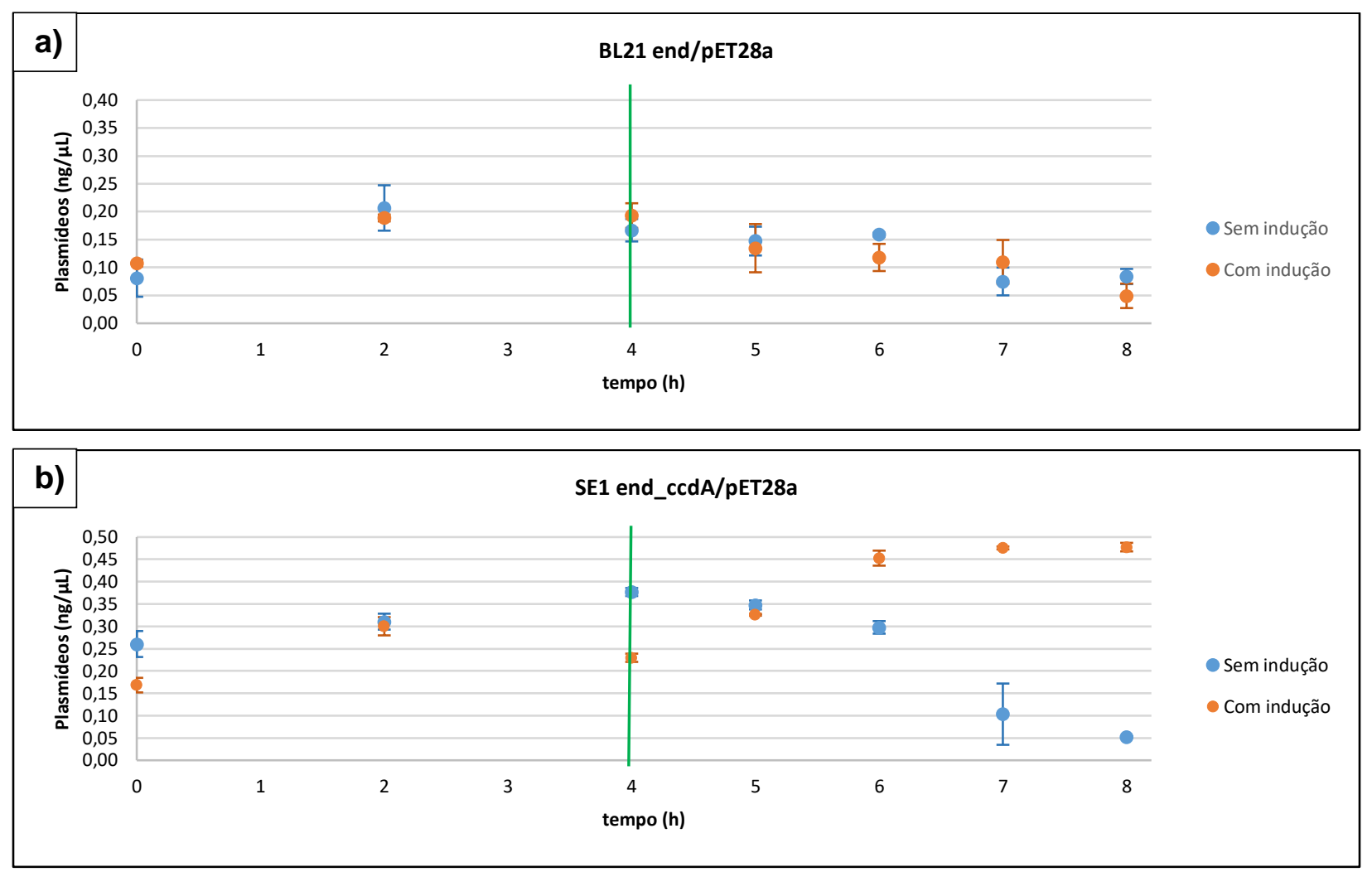

Figura 14 - Número de cópias de plasmídeos por reação ao longo do cultivo. A linha verde indica o momento da indução. a) Linhagem BL21(DE3) com o plasmídeo end/pET28a. b) linhagem SE1 com o plasmídeo end_ccdA/pET28a. 


\subsection{Determinação da concentração do indutor}

Visando reduzir os efeitos da sobrecarga metabólica, foram conduzidos experimentos para verificar a possibilidade da redução da concentração de IPTG na indução. Num primeiro momento, este experimento foi conduzido em microtubos e a faixa de concentrações testadas foi de $0,01 \mathrm{mM}$ a $1 \mathrm{mM}$ de IPTG (Figura 15), com o clone da linhagem SE1 expressando a enzima endoglucanase.

Do experimento realizado em microensaio, foi possível verificar, através do gel de SDS-PAGE, a expressão da proteína a partir da concentração de 0,05 mM de IPTG. As amostras coletadas tiveram a proteína total dosada e, através de densitometria após SDS-PAGE, foi possível calcular a quantidade de proteína recombinante em cada amostra (Tabela 8).

A fim de verificar se o resultado seria reproduzido em condições controladas de cultivo (aeração, temperatura, agitação), o experimento para determinação da concentração de IPTG com o clone da linhagem SE1 expressando a enzima endoglucanase foi realizado em reatores, num volume de $150 \mathrm{~mL}$ de cultivo, avaliandose também a atividade enzimática da proteína expressa. Amostras após a terceira hora de indução foram coletadas e foram avaliadas quanto à produção de proteínas totais, proteína recombinante, atividade enzimática e atividade específica (Tabela 9).

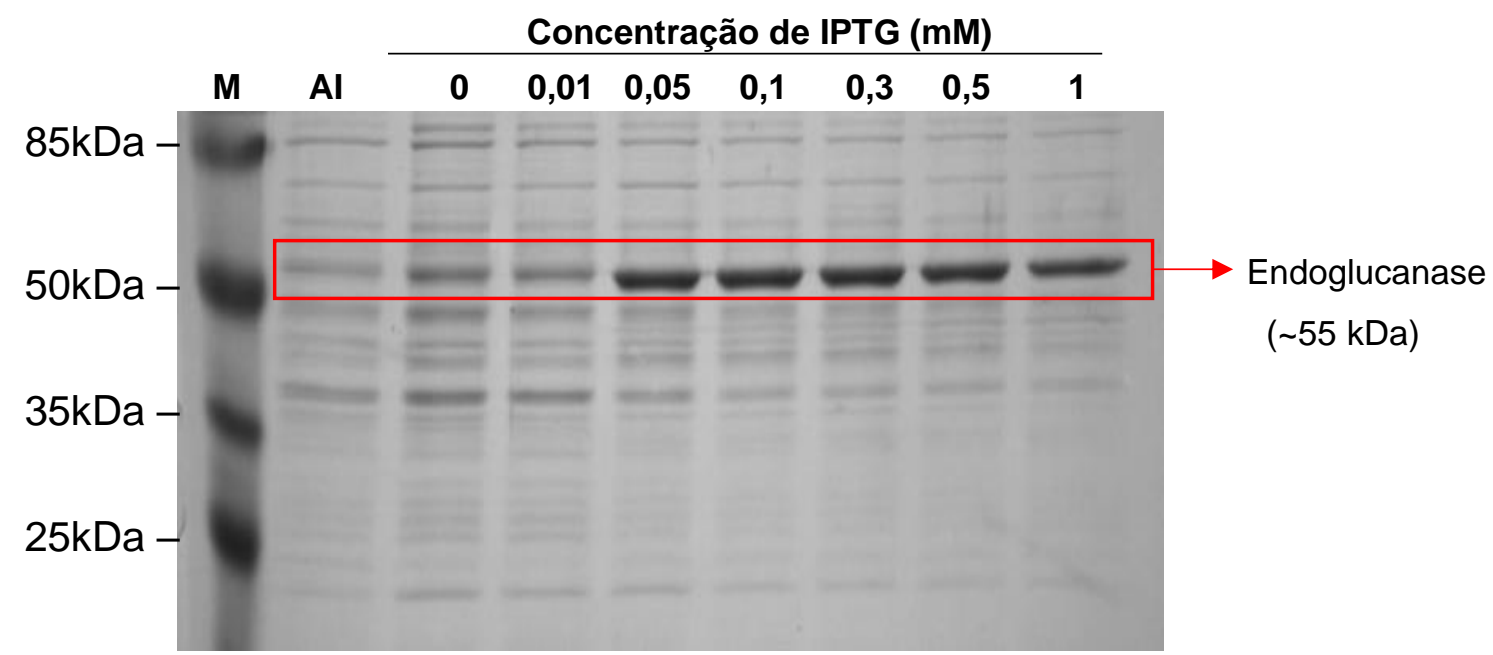

Figura 15 - Gel de SDS-PAGE com amostras após 3 horas de indução da enzima endoglucanase na linhagem SE1 com diferentes concentrações de IPTG. M: marcador de peso molecular (Prestained Protein MW Marker - ThermoScientific). Al: amostra antes da indução. 
Tabela 8 - Dados obtidos no microensaio de determinação da concentração do indutor IPTG.

\begin{tabular}{ccccc}
\hline $\begin{array}{c}\text { Concentração } \\
\text { de IPTG (mM) }\end{array}$ & $\begin{array}{c}\text { Proteína } \\
\text { Recombinante (\%) }\end{array}$ & $\begin{array}{c}\text { Proteína } \\
\text { total } \mathbf{( g / L )}\end{array}$ & $\begin{array}{c}\text { Biomassa na } \\
\text { indução }(\mathbf{g} / \mathbf{L})\end{array}$ & $\begin{array}{c}\text { Biomassa } \\
\text { final } \mathbf{( g / L} \mathbf{L})\end{array}$ \\
\hline $\mathbf{0}$ & $11,9 \pm 1,0$ & $0,3 \pm 0,1$ & 1,0 & $2,4 \pm 0,0$ \\
$\mathbf{0 , 0 1}$ & $10,7 \pm 0,4$ & $0,2 \pm 0,0$ & 1,0 & $2,5 \pm 0,3$ \\
$\mathbf{0 , 0 5}$ & $31,7 \pm 1,8$ & $0,3 \pm 0,0$ & 1,0 & $2,2 \pm 0,2$ \\
$\mathbf{0 , 1 0}$ & $30,6 \pm 2,9$ & $0,3 \pm 0,0$ & 1,0 & $1,8 \pm 0,2$ \\
$\mathbf{0 , 3 0}$ & $27,2 \pm 1,2$ & $0,3 \pm 0,0$ & 1,0 & $1,8 \pm 0,0$ \\
$\mathbf{0 , 5 0}$ & $28,1 \pm 0,3$ & $0,3 \pm 0,0$ & 1,0 & $1,8 \pm 0,0$ \\
$\mathbf{1 , 0 0}$ & $30,9 \pm 4,9$ & $0,3 \pm 0,0$ & 1,0 & $1,7 \pm 0,0$ \\
\hline
\end{tabular}

Tabela 9 - Dados obtidos no ensaio em reatores para determinação da concentração do indutor IPTG.

\begin{tabular}{lccccccc}
\hline & \multicolumn{7}{c}{ Concentração de IPTG (mM) } \\
\cline { 2 - 8 } & $\mathbf{0 , 0 0}$ & $\mathbf{0 , 0 2 5}$ & $\mathbf{0 , 0 5}$ & $\mathbf{0 , 1 0}$ & $\mathbf{0 , 2 5}$ & $\mathbf{0 , 5 0}$ & $\mathbf{1 , 0 0}$ \\
\hline $\begin{array}{l}\text { Proteína } \\
\text { recombinante (\%) }\end{array}$ & $11,9 \pm 0,9$ & $11,6 \pm 0,3$ & $14,6 \pm 1,3$ & $18,6 \pm 0,5$ & $24,0 \pm 0,1$ & $38,6 \pm 2,7$ & $49,2 \pm 0,8$ \\
$\begin{array}{l}\text { Proteína total (g/L) } \\
\text { Atividade (U/mL) }\end{array}$ & $1,0 \pm 0,1$ & $0,8 \pm 0,1$ & $1,3 \pm 0,3$ & $0,8 \pm 0,0$ & $1,0 \pm 0,1$ & $1,0 \pm 0,1$ & $1,3 \pm 0,2$ \\
$\begin{array}{l}\text { Atividade } \\
\text { específica (U/mg) }\end{array}$ & 2,3 & 2,0 & 3,3 & 3,3 & 4,2 & 4,4 & 5,3 \\
$\begin{array}{l}\text { Biomassa na } \\
\text { indução (g/L) }\end{array}$ & $2,2 \pm 0,1$ & $2,2 \pm 0,1$ & $3,0 \pm 0,0$ & $3,0 \pm 0,2$ & $2,2 \pm 0,4$ & $2,4 \pm 0,1$ & $2,6 \pm 0,2$ \\
$\begin{array}{l}\text { Biomassa final } \\
\text { (g/L) }\end{array}$ & $5,7 \pm 0,2$ & $4,9 \pm 0,0$ & $5,3 \pm 0,1$ & $5,3 \pm 0,0$ & $4,9 \pm 0,0$ & $5,0 \pm 0,0$ & $6,1 \pm 0,5$ \\
\hline
\end{tabular}




\section{DISCUSSÃO}

No intuito de reduzir custos no processo produtivo de proteínas heterólogas, o presente trabalho avaliou a performance de um sistema de estabilização de plasmídeo pouco estudado para tal finalidade, o sistema toxina-antitoxina, comparado ao sistema amplamente utilizado industrialmente na atualidade, que é baseado em antibióticos. Os sistemas de estabilização estudados neste trabalho utilizam o mesmo vetor de expressão ( $\mathrm{pET}-28 \mathrm{a}$ ), porém um deles utiliza um gene presente no plasmídeo que expressa uma proteína que degrada o antibiótico e o outro é baseado num gene que codifica para uma proteína antitoxina, capaz de inibir a atividade da toxina codificada em um gene presente no DNA genômico da célula. Para o primeiro caso, foi utilizada a linhagem BL21(DE3) e, no outro, a linhagem modificada SE1, a qual apresenta em seu DNA genômico o gene que expressa a toxina.

A partir dos dados de parâmetros cinéticos obtidos para a linhagem SE1 para obtenção de expansina e endoglucanase, é possível observar que o comportamento de ambos os clones é praticamente o mesmo. Neste caso, a célula hospedeira é a mesma e, apesar de as construções do plasmídeo que cada uma carrega serem diferentes quanto ao inserto, expressando proteínas em torno de $23 \mathrm{kDa}$ (expansina) e $55 \mathrm{kDa}$ (endoglucanase), o perfil de crescimento das células não foi alterado. $O$ fato de apresentarem o mesmo perfil cinético é um ponto que permitirá, por exemplo, em estudo de cultivo em co-cultura.

É possível observar dos ensaios de expressão em frascos agitados que a quantidade de células presente no final do cultivo, avaliada pela densidade óptica, é semelhante entre as linhagens BL21(DE3) e SE1. Em experimento realizado por Szpirer e Milinkovitch, em 2005, em que o sistema toxina-antitoxina em linhagem SE1 foi comparado ao cultivo com BL21(DE3) sem a presença de antibióticos, foi observado um crescimento maior com a linhagem BL21(DE3).

Entre os clones de endoglucanase e expansina, observa-se que o perfil de crescimento é semelhante, atingindo densidades ópticas finais também semelhantes, tanto na cinética sem indução como com indução. No entanto, ao se comparar os resultados dos ensaios entre as linhagens SE1 e BL21(DE3), verifica-se que, sem 
indução, a linhagem SE1 possui uma velocidade de crescimento superior, atingindo densidades celulares em torno de 50\% superiores. Entretanto, ao adicionar o indutor, a velocidade de crescimento da linhagem SE1 foi significativamente reduzida (Figura 16). A presença do DNA plasmidial e a expressão da proteína recombinante causam um desvio nas fontes energéticas da célula que seriam destinadas ao seu crescimento. Como apontado por Donovan e colaboradores (1996), esta sobrecarga metabólica geralmente leva a uma redução na taxa de crescimento celular, causa instabilidade plasmidial segregacional e estrutural e pode causar mudanças metabólicas, genéticas e fisiológicas. No entanto, tal comportamento não foi observado nos resultados obtidos com a linhagem BL21(DE3) e concorda com dados reportados por Olaofe e colaboradores (2010), cujo trabalho para expressão de uma enzima na linhagem BL21(DE3) demonstrou que não houve diferença significativa no crescimento das células comparando o cultivo controle (sem indução) ao cultivo com indução em concentrações entre 40 a $1000 \mu \mathrm{M}$ de IPTG.
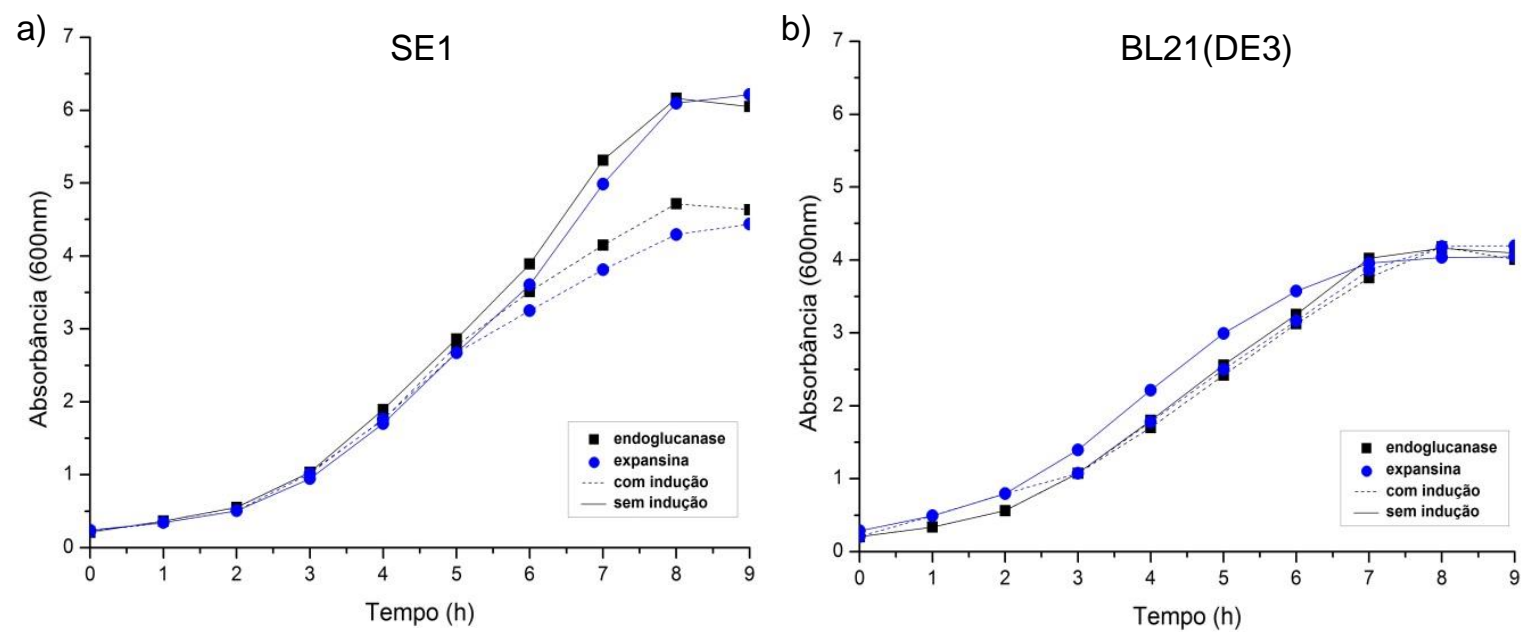

Figura 16 - Comparação do perfil cinético de crescimento das linhagens SE1 e BL21(DE3) com e sem indução em ensaios em frasco agitado. 16a) Cinética de crescimento da linhagem SE1. 16b) Cinética de crescimento da linhagem BL21(DE3).

Discute-se que o efeito negativo sobre o crescimento da célula é dado ao desvio energético para a produção da proteína, uma vez que a célula tende a balancear a 
sobrecarga metabólica do crescimento celular e expressão da proteína (OLAOFE et al., 2010). Quando observamos os resultados da avaliação da estabilidade plasmidial, foi verificado que o perfil do número de cópias de plasmídeos presente por célula na linhagem BL21(DE3) é, em geral, o mesmo sem indução ou com indução (Figura 14a), ou seja, neste sistema não se observa impacto da indução sobre a formação de biomassa e nem sobre o número de cópias do plasmídeo por célula. No entanto, na linhagem SE1, é possível observar uma grande diferença no número de cópias de plasmídeos após a indução. Na Figura 14b verifica-se que o número de plasmídeos por célula aumenta, fato que poderia explicar a diminuição da velocidade de crescimento na linhagem SE1 e não na BL21(DE3). O fato de a célula estar carregando um maior número de cópias do plasmídeo poderia levar a uma sobrecarga metabólica maior, fazendo com que a energia que antes estava sendo destinada ao crescimento celular, seja então destinada à manutenção dos plasmídeos e produção da proteína recombinante.

Ainda com relação à estabilidade plasmidial, verifica-se que no sistema dependente de antibiótico com a linhagem BL21(DE3) há perda do plasmídeo, mesmo com a presença do antibiótico responsável pela pressão seletiva, confirmando resultados já apresentados por Zabriskie e Acuri (1986). Dos resultados anteriormente apresentados, a quantidade de células obtidas ao final dos cultivos após expressão é semelhante em ambas as linhagens, SE1 e BL21(DE3), apontando também uma sobrecarga metabólica. No entanto, diferentemente do sistema de estabilização dependente de antibióticos, não haverá uma sobreposição da população de células sem plasmídeos, uma vez que a expulsão do plasmídeo causará a morte celular. Consequentemente, não haverá competição dos nutrientes com células sem 0 plasmídeo e, indo além da disponibilidade dos recursos nutritivos no meio, a morte celular causada pela expulsão do plasmídeo pode estimular o crescimento das células ainda viáveis, como apontado por Corchero e colaboradores (2001), através da utilização dos metabólitos liberados pelas células lisadas. A consequência do ponto de vista do processo é a maior produção de proteína recombinante empregando a linhagem SE1 (Tabela 4). 
Com relação à utilização do IPTG como indutor, apesar de ampla extensão de concentrações ter sido reportada, variando-se de 0,005 a $5 \mathrm{mM}$, a expressão é geralmente realizada com uma concentração final a $1 \mathrm{mM}$, independente da densidade celular da cultura, haja visto que esta molécula não é metabolizada pela célula (DONOVAN et al., 1996). Tal concentração, considerada em excesso, tem sido utilizada no intuito de induzir completamente o operador lac, resultando numa maior expressão do gene. Apesar de a ideia ser atraente, não necessariamente uma concentração maior de indutor levará à maior expressão da proteína recombinante (GLICK, 1995), uma vez que há um maior potencial para instabilidade plasmidial e outras alterações metabólicas, principalmente em larga escala (DONOVAN et al., 1996). Além disto, o IPTG certamente contribui com uma parcela significativa do custo do produto sendo desejável a redução da concentração.

Ao comparar os resultados do estudo da concentração do indutor em microtubos e em reatores, observa-se que a redução de escala obteve um ótimo resultado qualitativo, sendo o resultado em ambos os casos bem semelhante, ou seja, em ambos a síntese pôde ser observada a partir de 0,05 mM de IPTG. No entanto, para um resultado quantitativo, o experimento em reatores mostrou-se mais eficaz. Esta diferença pode ser devido ao estresse proporcionado às células nos microtubos, associado a um sistema não controlado, principalmente quanto à disponibilidade de oxigênio. Analisando a validade do estudo em microensaio, pode-se dizer que há a grande vantagem da simplicidade do método, pois oferece a possibilidade de realizar uma série de "mini-cultivos" paralelos para uma triagem inicial. Em seguida, é interessante realizar em condições controladas, cultivos em reatores para avaliar quantitativamente os resultados, utilizando os principais pontos selecionados após a análise qualitativa.

Do experimento realizado nos reatores, foi possível verificar que, diferentemente do que foi encontrado no microensaio, a expressão da proteína recombinante foi proporcional ao aumento da concentração de IPTG adicionado no momento da indução. No microensaio, observa-se que o aumento da concentração de IPTG não favoreceu a expressão da proteína recombinante, tendo-se obtido a máxima expressão na concentração de 0,05 mM IPTG. Outro ponto importante a se destacar foi que, no 
ensaio em microtubos, a concentração de $0,05 \mathrm{mM}$ foi suficiente para produzir $31,7 \%$ de proteína recombinante, enquanto que nos reatores a produção foi de 14,6\%. Esta diferença pode estar relacionada à quantidade de células presentes no momento da indução. Por haver menor quantidade de células no microtubos, as moléculas de IPTG poderiam estar mais disponíveis do que nos reatores.

A vantagem da utilização do IPTG é que, ao contrário da lactose, não é um substrato da $\beta$-galactosidase e, portanto, não é metabolizado (HANSEN et al., 1998), não sendo necessária a reposição da molécula durante a indução. No entanto, torna-se necessária a atenção na concentração do indutor considerando a concentração de células, que pode influenciar na disponibilidade do indutor com relação a uma única célula, no caso de baixas concentrações de indutor. Fernandéz-Castané e colaboradores (2012) realizaram estudo considerando esta relação da concentração de indutor e concentração de biomassa, em alta densidade celular. Nos experimentos, verificaram a expressão da proteína analisando a concentração de IPTG dentro e fora da célula e concluíram que a maior quantidade de IPTG permanece no meio para alcançar o equilíbrio com o nível intracelular, sendo que a taxa de transporte do indutor para o interior da célula é algo importante a se considerar. Sendo assim, no presente estudo, apesar de a concentração mínima de IPTG encontrada para a completa indução do sistema tenha sido estabelecida, é importante destacar que são condições para cultivos em bateladas simples, em que não é atingida uma alta densidade celular. Para altas densidades, seria cauteloso considerar uma concentração mais elevada, como por exemplo aquela reportada por Fernandéz-Castané et al., 2012, ou realizar um estudo específico para o sistema de expressão em estudo considerando a diferença do inserto, tamanho do plasmídeo, linhagem de $E$. coli, para garantir completa indução. 


\section{CONCLUSÕES}

Os parâmetros cinéticos obtidos indicaram que a velocidade específica de crescimento das linhagens SE1 e BL21(DE3) foram semelhantes, ou seja, o sistema de estabilidade do plasmídeo utilizando a estratégia toxina-antitoxina foi tão eficiente quanto o sistema dependente do antibiótico com relação ao perfil de crescimento. A indução através de adição de IPTG afetou fortemente a velocidade específica de crescimento e a formação de biomassa da linhagem SE1. Apesar disto, a expressão das proteínas recombinantes foi superior àquela observada para o cultivo com a linhagem BL21(DE3). Os demais parâmetros cinéticos obtidos dos clones de endoglucanase e expansina na linhagem SE1 apresentaram-se semelhantes, ponto positivo no caso de um futuro trabalho de produção destas enzimas em co-cultura, o que auxiliaria na redução de custos na produção de misturas enzimáticas.

No caso do aumento de escala para produção de proteínas heterólogas, é interessante realizar um estudo econômico considerando a quantidade de proteína recombinante expressa, a quantidade do indutor e seu custo. Pelo alto custo do IPTG, é desejável que a sua concentração seja reduzida na fase de indução. Neste projeto, foi possível chegar a uma concentração mais reduzida para a expressão da enzima endoglucanase. No entanto, como observado no ensaio em reator, em condições controladas e maior densidade celular, a expressão da proteína foi proporcional à quantidade de indutor adicionada. Além disso, é importante considerar a quantidade de células presentes no momento da indução.

Por fim, foi possível demonstrar a eficácia do sistema toxina-antitoxina quanto à estabilização do plasmídeo e, ainda, sua vantagem quando comparado ao sistema dependente de antibiótico. Além dos inconvenientes citados sobre a utilização de antibióticos em processos industriais (questões regulatórias e financeiras), a utilização deste não garante a total seleção de clones positivos. Sendo assim, o sistema de estabilização plasmidial toxina-antitoxina para a produção de proteínas recombinantes em Escherichia coli mostrou-se como uma alternativa eficaz para o desenvolvimento de processos de produção. 


\section{REFERÊNCIAS*}

AAKRE, C. D.; PHUNG, T. N.; HUANG, D.; LAUB, M. T. A bacterial toxin inhibits DNA replication elongation through a direct interaction with the beta sliding clamp. Molecular Cell. v. 52, p. 617-628, 2013.

AFIF, H.; ALLALI, N.; COUTURIER, M.; VAN MELDEREN, L. The ratio between CcdA and $\mathrm{CcdB}$ modulates the transcriptional repression of the ccd poison-antidote system. Molecular Microbiology, v. 41, p. 73-8, 2001.

ALVIRA, P.; NEGRO, M. J.; BALLESTEROS M. Effect of endoxylanase and $\alpha-L-$ arabinofuranosidase supplementation on the enzymatic hydrolysis of steam exploded wheat straw. Bioresource Technology, v. 101, p. 4552-4558, 2011.

BALAT, M. Production of bioethanol from lignocellulosic materials via the biochemical pathway: A review. Energy Conversion and Management, v. 52, p.858-875, 2010.

BANERJEE, G.; CAR, S.; SCOTT-CRAIG, J. S.; BORRUSCH, M. S.; BONGERS, M; WALTON, J.D. Synthetic multi-component enzyme mixtures for deconstruction of lignocellulosic biomass. Bioresource Technology, v. 101, p. 9097-9105, 2010.

BAESHEN, M. N.; AL-HEJIN, A. M.; BORA, R. S.; AHMED, M. M. M.; RAMADAN, H. A. I.; SAINI, K. S.; BAESHEN, N. A.; REDWAN, E. M. Production of Biopharmaceuticals in E. coli: Current Scenario and Future Perspectives. Journal of Microbiology and Biotechnology, v. 25, p. 953-962, 2015.

BANEYX, F. Recombinant protein expression in Escherichia coli. Current Opinion in Biotechnology, v. 10, p. 411-421, 1999.

BERNARD, P.; COUTURIER, M. Cell killing by the $\mathrm{F}$ plasmid CcdB protein involves poisoning of DNA-topoisomerase II complexes. Journal of Molecular Biology, v. 226, p. 735-745, 1992.

BERNARD, P.; KEZDY, K. E.; VAN MELDEREN, L.; STEYAERT, J.; WYNS, L.; PATO, M. L.; HIGGINS, P. N.; COUTURIER, M. The F plasmid CcdB protein induces efficient ATP-dependent DNA cleavage by gyrase. Journal of Molecular Biology, v. 234, p. 534-541,1993.

BRADFORD, M.M. A rapid and sensitive method for the quantitation of microgram quantities of protein utilizing the principle of protein-dye binding. Analytical Biochemistry, v. 72, p. 248-254, 1976.

\footnotetext{
*De acordo com:

ASSOCIAÇÃO BRASILEIRA DE NORMAS TÉCNICAS. NBR6023: informação e documentação: referências: elaboração. Rio de Janeiro, 2002.
} 
CARAPUÇA, E.; AZZONI, A.R.; PRAZERES, D.M.F.; MONTEIRO, G.A.; MERGULHA, F.J.M. Time-course determination of plasmid content in eukaryotic and prokaryotic cells using Real-Time PCR. Molecular Biotechnology, v. 37, p. 120-126, 2007.

CHENG, L-C.; HOR, L-I.; WU, J-Y.; CHEN, T-L. Effect of specific growth rate on the production of a recombinant nuclease by Escherichia coli. Biochemical Engineering Journal, v. 14, p. 101-107, 2003.

CHOI, J.H.; KEUM, K.C.; LEE, S.Y. Production of recombinant proteins by high cell density culture of Escherichia coli. Chemical Engineering. Science, v. 61, p. 876-885, 2006.

CORCHERO, J. L.; CUBERSÍ, R.; VILA, P.; ARÍS, A.; VILLAVERDE, A. Cell lysis in Escherichia coli cultures stimulates growth and biosynthesis of recombinant proteins in surviving cells. Microbiological Research, v. 156, p. 13-18, 2001.

DONOVAN, R. S.; ROBINSON, C.W.; GLICK, B.R. Review: Optimizing inducer and culture conditions for expression of foreign proteins under the control of the lac promoter. Journal of Industrial Microbiology, v. 16, p. 145-154, 1996.

FARGIONE, J.; HILL, J.; TILMAN, D.; POLASKY, S.; HAWTHORNE, P. Land clearing and the biofuel carbon debt. Science, v. 319, p. 1235-1238, 2008.

FERNANDÉZ-CASTANÉ, A.; CAMINAL, G.; LÓPEZ-SANTÍN, J. Direct measurements of IPTG enable analysis of the induction behavior of E.coli in high cell density cultures. Microbial Cell Factories, v. 11, p. 58-66, 2012.

FINERAN, P. C.; BLOWER, T. R.; FOULDS, I. J.; HUMPHREYS, D. P.; LILLEY, K. S.; SALMOND, G. P. The phage abortive infection system, ToxIN, functions as a proteinRNA toxin-antitoxin pair. Proceedings of the National Academy of Sciences of the United Nations of America, v.106, p. 894-899, 2009.

FOZO, E. M.; HEMM, M. R.; STORZ, G. Small toxic proteins and the antisense RNAs that repress them. Microbiology and Molecular Biology Reviews, v. 72, p. 579-589, 2009.

FRIEHS, K. Plasmid copy number and plasmid stability. New Trends and Developments in Biochemical Engineering, v. 86, p. 47-82, 2004.

GERDES, K.; MAISONNEUVE, E. Bacterial persistence and toxin-antitoxin loci. Annual Review of Microbiology, v. 66, p. 103-123, 2012.

GHOSE, T.K. Measurement of cellulase activities. Pure Applied Chemistry, v. 59, p. 257-268, 1987. 
GLICK, B.R. Metabolic load and heterologous gene expression. Biotechnology Advances, v. 13, p. 247-261, 1995.

GUPTA, R.; SHARMA, P.; VYAS, V.V. Effect of growth environment on the stability of a recombinant shuttle plasmid, pCPPS-31, in Escherichia coli. Journal of Biotechnology, v. 41, p. 29-37, 1995.

HANSEN, L. H.; KNUDSEN, S.; SORENSEN, S.J. The Effect of the lacY Gene on the induction of IPTG inducible promoters, studied in Escherichia coli and Pseudomonas fluorescens. Current Microbiology, v. 36, p. 341-347, 1998.

HESS, M. Thermoacidophilic proteins for biofuel production. Trends in Microbiology, v. 16, p. 414-419, 2008.

LAEMMLI, U.K. Cleavage of structural proteins during the assembly of the head of bacteriophage T4. Nature, v. 2273, p. 397-407, 1970.

LEE, S.Y. High cell density culture of Escherichia coli. Trends in Biotechnology, v. 14, p. 98-105, 1996.

MAKI, S.; TAKIGUCHI, S.; MIKI, T.; HORIUCHI, T. Modulation of DNA supercoiling activity of Escherichia coli DNA gyrase by $\mathrm{F}$ plasmid proteins. Antagonistic actions of Let $A(\mathrm{Ccd} A)$ and LetD $(\mathrm{CcdB})$ proteins. Journal of Biological Chemistry, v. 267, p. 12244-12251, 1992.

MASUDA, H.; TAN, Q.; AWANO, N.; YAMAGUCHI, Y.; INOUYE, M. A novel membrane-bound toxin for cell division, CptA (YgfX), inhibits polymerization of cytoskeleton proteins, FtsZ and MreB, in Escherichia coli. FEMS Microbiology Letters, v. 328, p.174-181, 2012.

MEYER, A. S.; ROSGAARD, L.; SORENSEN, H.R. The minimal enzyme cocktail concept for biomass processing. Journal of Cereal Science, v. 50, p. 337-344, 2009.

MILLER, G.L. Use of dinitrosalicylic acid reagent for determination of reducing sugar. Analytical Chemistry, v. 31, p. 426-428, 1959

MUSSATTO, S. I.; DRAGONE, G.; GUIMARÃES, P.M. R.; SILVA, J.P. A.; CARNEIRO, L. M.; ROBERTO, I. C.; VICENTE, A.; DOMINGUES, L.; TEIXEIRA, J.A. Technological trends, global market, and challenges of bio-ethanol production. Biotechnology Advances, v. 28, p. 817-830, 2010.

NAGENDRAN, S.; HALLEN-ADAMS, H.E.; PAPER, J.M.; ASLAM, N.; WALTON, J.D. Reduced genomic potential for secreted plant cell wall degrading enzymes in the ectomycorrhizal fungus Amanita bisporigera, based on the secretome of Trichoderma reesei. Fungal Genetics and Biology, v. 46, p. 427-435, 2009. 
OGURA, T.; HIRAGA, S. Mini-F plasmid genes that couple host cell division to plasmid proliferation. Proceedings of the National Academy of Sciences of the United States of America, v. 80, p. 4784-4788, 1983.

OLAOFE, O.A.; BURTON, S. G.; COWAN, D. A.; HARRISON, S. T. L. Improving the production of a thermostable amidase through optimizing IPTG induction in a highly dense culture of recombinant Escherichia coli. Biochemical Engineering Journal, v. 52, p.19-24, 2010.

PEUBEZ, I.; CHAUDET, N.; MIGNON, C.; HILD, G.; HUSSON, S.; COURTOIS, V.; DE LUCA, K.; SPECK, D.; SODOYER, R. Antibiotic-free selection in E. coli: new considerations for optimal design and improved production. Microbial Cell Factories, Londres, v. 9, n. 65, set. 2010. Disponível em <http://doi.org/10.1186/1475-2859-9-65>.

RODRIGUEZ, V.; ASENJO, J. A.; ANDREWS, B. A. 2014. Design and implementation of a high yield production system for recombinant expression of peptides. Microbial Cell Factories, Londres, v. 13, n. 65, abr./mai. 2014. Disponível em <http://doi.org/10.1186/1475-2859-13-65>.

ROCKER, A.; MEINHART, A. Type II toxin: antitoxin systems. More than small selfish entities? Current Genetics, v. 61, p. 287-290, 2016.

SAHDEV, S.; KHATTAR, S. K.; SAINI, K. S. Production of active eukaryotic proteins through bacterial expression systems: a review of the existing biotechnology strategies. Molecular and Cellular Biochemistry, v. 307, p. 249-264, 2008.

SALOHEIMO, M.; PALOHEIMO, M.; HAKOLA, S.; PERE, J.; SWANSON, B.; NYYSSÖNEN, E.; BHATIA, A.; WARD, M.; PENTTILÄ, M. Swollenin, a Trichoderma reesei protein with sequence similarity to the plant expansins, exhibits disruption activity on cellulosic materials. European Journal of Biochemistry, v. 269, p. 4202-4211, 2002.

SCHUSTER, C. F.; BERTRAM, R. Toxin-antitoxin systems are ubiquitous and versatile modulators of prokaryotic cell fate. FEMS Microbiology Letters, v. 340, p. 73-85, 2013.

SEARCHINGER, T.; HEIMLICH, R.; HOUGHTON, R.A.; DONG, F.; ELOBEID, A.; FABIOSA, J.; TOKGOZ, S.; HAYES, D.; YU, T-H. Use of US croplands for biofuels increases greenhouse gases through emissions from land use change. Science, v. 319, p. $1238-1240,2008$.

SHILOACH, J.; FASS, R. Growing E. coli to high cell density - A historical perspective on method development. Biotechnology Advances, v. 23, p. 345-357, 2005.

SIMS, R.E.H.; MABEE, W.; SADDLER, J.N.; TAYLOR, M. An overview of second generation biofuel Technologies. Bioresource Technology, v. 10, p. 1570-1580, 2009. 
SODOYER, R.; COURTOIS, V.; PEUBEZ, I.; MIGNON, C. Antibiotic-Free Selection for Bio-Production: Moving Towards a New "Gold Standard". In: PANA, M. Antibiotic Resistant Bacteria - A Continuous Challenge in the New Millennium. Rijeka: InTech, 2012, cap. 25, p. 531-548.

SZPIRER, C.Y.; MILINKOVITCH, M.C. Separate-component-stabilization system for protein and DNA production without the use of antibiotics. Biotechniques, v. 38, p. 775-778, 2005.

UNTERHOLZNER, S. J.; POPPENBERGER, B.; ROZHON, W. Toxin-antitoxin systems: Biology, identification, and application. Mobile Genetic Elements, Abingdon, v. 3, n. 5, set./out. 2013. Disponível em <http://doi.org/10.4161/mge.26219>.

VAN DYK, J.S.; PLETSCHKE, B.I. A review of lignocellulose bioconversion using enzymatic hydrolysis and synergistic cooperation between enzymes-Factors affecting enzymes, conversion and synergy. Biotechnology Advances, v. 30, p. 1458-1480, 2012.

VAN MELDEREN, L.; BERNARD, P.; COUTURIER, M. Lon-dependent proteolysis of CcdA is the key control for activation of $\mathrm{CcdB}$ in plasmid-free segregant bacteria. Molecular Microbiology, v. 11, p. 1151-1157, 1994.

VAN MELDEREN, L.; THI, M. H.; LECCHI, P.; GOTTESMAN, S.; COUTURIER, M.; MAURIZI, M. R. ATP-dependent degradation of CcdA by Lon protease. Effects of secondary structure and heterologous subunit interactions. Journal of Biological Chemistry, v. 271, p. 27730-27738, 1996.

WANG, X.; LORD, D. M.; CHENG, H. Y.; OSBOURNE, D.O.; HONG, S. H.; SANCHEZTORRES, V.; QUIROGA, C.; ZHENG, K.; HERMANN, T.; PETI, W.; BENEDIK, M. J.; PAGE, R.; WOOD, T. K. A new type $V$ toxin antitoxin system where mRNA for toxin GhoT is cleaved by antitoxin GhoS. Nature Chemical Biology, v. 8, p. 855-861, 2012.

YAMAGUCHI, Y.; PARK, J. H.; INOUYE, M. Toxin-antitoxin systems in bacteria and archaea. Annual Review of Genetics, v. 45, p. 61-79, 2011.

ZABRISKIE, D.W.; ACURI, E.J. Factors influencing productivity of fermentations employing recombinant microorganisms. Enzyme Microbial Technology, v. 8, p. 706$717,1986$. 